\title{
Novija historiografija o grkokatoličkoj Marčanskoj (Svidničkoj/ Platejskoj) biskupiji i crkvenoj uniji u Hrvatskoj **
}

\begin{abstract}
Autor analizira noviju domaću i inozemnu historiografiju o Marčanskoj (Svidničkoj/Platejskoj) biskupiji i crkvenoj uniji na području Hrvatsko-slavonske vojne krajine. Ukazuje na razlike u interpretacijama kod pojedinih autora i na moguće izvore njihovih zaključaka.

Ključne riječi: historiografija, crkvena unija, pravoslavlje, Marčanska biskupija, Zagrebačka biskupija, Pećka patrijaršija, Bečki dvor, Rimska kurija, Hrvatsko-slavonska vojna krajina, Vlasi
\end{abstract}

Povijest crkvene unije u Hrvatskoj i grkokatoličke Marčanske (Svidničke/Platejske) biskupije, utemeljene breveom pape Pavla V. "Divine Miestatis Arbitrio" od 21. studenog 1611. godine ${ }^{1}$ tema je različitih radova i monografija objavljenih od druge polov-

\footnotetext{
* Zlatko Kudelić, Hrvatski institut za povijest, Opatička 10, 10000 Zagreb, Republika Hrvatska, E-mail adresa: zkudelic@isp.hr

** Rad je nastao na temelju izlaganja pod naslovom "Dosezi istraživanja o Marčanskoj biskupiji u novijoj historiografiji" na Međunarodnome znanstvenom skupu o obnovi crkvenoga zajedništva u Hrvatskoj i osnutku grkokatoličke biskupije u Marči održanome u Zagrebu u Hrvatskome institutu za povijest 9.-11. svibnja 2012. godine.

1 Spomenutim breveom njezinomu prvom biskupu Simeonu Vratanji kao jurisdikcijsko područje određene su Ugarska, Hrvatska, Slavonija i krajnji dijelovi Kranjske, to jest Žumberak. Iako ju je u historiografiji postalo uobičajeno nazivati Marčanskom, po mjestu Marča blizu današnjega Kloštar Ivanića u kojemu je prema papinskome breveu na ostacima katoličke crkve Svih Svetih biskup Simeon još prije posvećenja u Rimu počeo podizati crkvu i samostan, zbog prijepora oko prava imenovanja biskupâ između Beča i Rima Dvor ju je od 1642. godine nazivao Svidničkom, a Rimska kurija od 1671. do 1746. godine Platejskom biskupijom, dok je u pojedinim ispravama na latinskome jeziku spominjana i kao "biskupija Vlaha” (episcopatus Valachorum). Predzadnji svidnički (marčanski) biskup Gabrijel Palković (1751. - 1759.) u Rimu je imenovan druziparskim, a zadnji Bazilije (Vasilije) Božičković (1759. - 1789.) dioklecijanopoljskim biskupom. Potrebno je napomenuti da je pojam "grkokatolik" ušao u nazivlje tek od 1773. godine, za vladavine Marije Terezije, a prije njega uobičajen pojam za grkokatolike bio je "sjedinjeni", odnosno "nesjedinjeni" za pravoslavne kršćane. Opširnije: Janko Šimrak, Graeco-catholica Ecclesia in Jugoslavia. Dioecesis Crisiensis, olim Marčensis Historiae et hodiernus status, (Zagreb: Narodna prosvjeta, 1931), 11, 130, 133, 140; Drago Roksandić, Etnos, konfesija, tolerancija (Zagreb: SKD Prosvjeta, 2004), 72-73; Ernst Christoph Suttner, Staaten und Kirchen in der Völkerwelt des östlichen Europa. Entwicklungen der Neuzeit (Fribourg: Academic Press, 2007), 372-392, 414-418; Zlatko Kudelić, Marčanska biskupija. Habsburgovci, pravoslavlje i crkvena unija u Hrvatsko-slavonskoj vojnoj krajini (1611.-1755.) (Zagreb: Hrvatski institut za povijest, 2007), 165-169, 261-267, 275-281, 511-517; Nevenka Kauzlarić, Tragom marčanske povijesti (Kloštar Ivanić: "Otok Ivanić”, 2010), 8.
} 
ice 19. stoljeća do danas. ${ }^{2}$ Kako se problem unije pravoslavnih kršćana s Katoličkom crkvom tijekom 17. i 18. stoljeća u Hrvatskoj odnosio prvenstveno na područje Hrvatsko-slavonske vojne krajine (dalje: Vojne krajine), ova tema privukla je pozornost povjesničara Vojne krajine, autora sinteza povijesti Srpske pravoslavne crkve i Srba u Hrvatskoj, povjesničara iz Katoličke crkve te autora različitih sinteza hrvatske povijesti, koji su iznosili oprečne zaključke o njezinim počecima, ciljevima i dosezima, ovisno o historiografiji na koju su se oslanjali. ${ }^{3} \mathrm{U}$ ovome tekstu osvrnut ćemo se na radove koji su se o ovoj temi pojavili od početka devedesetih godina 20. stoljeća u hrvatskoj i inozemnoj historiografiji, "kada se pojavio veći interes za ovu temu potaknut između ostalog i aktualnim političkim zbivanjima s početka devedesetih godina prošlog stoljeća”, uz napomenu da zbog brojnosti nećemo analizirati radove srpske historiografije kojima je potrebno posvetiti poseban znanstveni rad jer se odnose i na povijest Srba u Hrvatskoj i Srpske pravoslavne crkve kao institucije. U Hrvatskoj su se u novije vrijeme ovom temom u prvom redu bavili povjesničari iz Katoličke crkve oslanjajući se najviše na radove dr. Janka Šimraka iz dvadesetih i tridesetih godina 20. stoljeća, ${ }^{4}$

2 Kudelić, Marčanska biskupija, 27-57, 539-561; Zlatko Kudelić, “Čaplovičeva povijest Marčanske biskupije”, Povijesni prilozi 29 (2010), br. 38: 135-180.

3 Od starije historiografije potrebno je spomenuti radove F. Hammerla o marčanskome biskupu Pavlu Zorčiću u sarajevskoj Vrhbosni s početka 20. stoljeća, koji su temeljeni na odgovarajućemu arhivskome gradivu iz Nadbiskupijskoga arhiva u Zagrebu. Radove pak srpskih povjesničara Manojla Grbića, Alekse Ivića, Vladimira Krasića, Đorđa Rajkovića, Dimitrija Ruvarca i Dimitrija Vitkovića od osamdesetih godina 19. stoljeća i tijekom prve polovice 20. stoljeća karakterizira pojmovna nepreciznost, pa i tendencioznost. Na primjer, M. Grbić u knjizi o Karlovačkome generalatu ustvrdio je bez ikakva uporišta u arhivskome gradivu da su senjski biskup Adam Rattkay i marčanski biskup Rafael Marković provodili 1713. i 1714. godine prisilno pokrštavanje Srba u Karlovačkome generalatu, a kao izvor podataka naveo je Sladovićevu knjigu o Senjskoj biskupiji, koji o tome u knjizi uopće ne govori. Drugi je primjer D. Ruvarac, koji je u tekstu iz 1904. godine naveo da su marčanskoga biskupa Pavla Zorčića u Rimu posvetila dva grčka, to jest po njemu pravoslavna episkopa (?!) i jedan latinski rimski biskup, iako se radilo o dva unijatska/grkokatolička biskupa. Opširnije: Manojlo Grbić, Karlovačko vladičanstvo: prilog $k$ istoriji Srpske pravoslavne crkve, knjiga I (Karlovac: Štamparija Karla Hauptfelda, 1891), 275, 279-289; Manojlo Sladović, Poviesti biskupiah senjske i modruške ili krbavske (Trst: Austrianski Lloyd, 1856); Dimitrije Ruvarac, "Gavrilo Mijakić i Pavle Zorčić - marčanske vladike”, Srpski Sion 14 (1904), br. 11: 311; Franjo Hammerl, "Pavao Zorčić - unijatski vladika. Povodom tristote godišnjice sjedinjenja naše braće unijata sa Rimskom crkvom 1611-1911”, Vrhbosna 25 (1911), br. 5: 68-72; br. 6: 83-88; br. 7/8: 101, 105; br. 9: 136-139; br. 10: 147-151; br. 11: 164-167; Kudelić, Marčanska biskupija, 3943.

4 Potrebno je napomenuti da je deset godina prije tiskanja Šimrakove knjige arhivskoga gradiva iz 1926. godine A. Ivić objavio 47 isprava o ovoj temi iz Nadbiskupijskog arhiva u Zagrebu, koje su obuhvaćale razdoblje od 1612. do 1685. godine, a D. Vitković 1918. godine je iz istoga arhiva objavio 27 pisama o djelovanju o patrijarha Arsenija III. Crnojevića tijekom 1704/1705. godine. Nakon njih M. Jačov u svojoj je zbirci gradiva iz 1986. godine, uz već neke poznate isprave koje su objavili J. Šimrak i D. Nežić, tiskao i nekoliko nepoznatih izvješća zagrebačkoga biskupa Benedikta Vinkovića i drugo gradivo o ovoj temi iz arhiva Kongregacije za širenje vjere za razdoblje između 1622. i 1644. godine. Osim J. Šimraka o povijesti ove biskupije pisali su i njegovi suvremenici A. Ivić, R. Grujić u spomenici posvećenoj Pakračkom vladičanstvu i J. Radonić, koji je istražujući odnos rimske kurije i južnoslavenskog prostora od 16. do 19. stoljeća koristio i arhivsko gradivo koje je objavio Šimrak. Nakon Drugoga svjetskog rata D. Kašić je o njoj pisao istražujući povijest Srpske pravoslavne crkve i povijesti pojedinih manastira. Opširnije: Aleksa Ivić, "Iz istorije crkve hrvatsko-slavonskih Srba tokom XVII. veka”, Vjesnik Kraljevskog hrvatsko-slavonsko-dalmatinskog zemaljskog arkiva 18 (1916), br. 2: 1-82; 19 (1917), 88-105; Dimitrije Vitković, “Patrijarh Arsenije III. Crnojević u Pakracu”, u: Starine Jugoslaven- 
ali ni domaća ni inozemna historiografija Vojne krajine nakon 1945. godine nisu uopće spominjale njegove radove niti njegovu spomenutu zbirku arhivskoga gradiva o ovoj temi iako ju možemo držati prvom značajnijom zbirkom arhivskoga gradiva za povijest Vojne krajine poslije Lopašićevih izdanja. ${ }^{5} \mathrm{Na}$ temelju Šimrakovih radova

ske akademije znanosti i umjetnosti 36, ur. Ferdo Šišić (Zagreb: JAZU, 1918), 163-208; Aleksa Ivić, "Marčanska episkopija od Simeona Vretanje do Gavrila Predojevića (1609.-1642.)", Brastvo 17 (1923): 156-166; Aleksa Ivić, "Marčanska episkopija od Gavrila Predojevića do Gavrila Mijakića (1642-1660)”, Brastvo 18 (1924): 87-100; Aleksa Ivić, “Marčanska episkopija od 1662 do 1670”, Brastvo 19 (1925): 196217; Aleksa Ivić, "Marčanska episkopija. Tragedija episkopa Mijakića i njegovih kaluđera”, Brastvo 20 (1926): 68-83; Janko Šimrak, De relationibus Slavorum Meridionalium cum Sancta Sede Apostolica saeculis XVII et XVIII (Zagreb: Hrvatska Bogoslovska Akademija, 1926); Radoslav Grujić, Pakračka eparhija. Istorijsko-statistički pregled. Spomenica o srpskom pravoslavnom vladičanstvu pakračkom u slavu četrdesetogodišnjice episkopstva, šezdesetogodišnjice svešteničke službe i osamdesetpetogodišnjice života vladike Mirona (Pakrac: Sveštenstvo vladičanstva Pakračkog, 1930), 43-142; Jovan Radonić, Rimska kurija i južnoslavenske zemlje od XVI. do kraja XIX. veka. Posebna izdanja (Srpska akademija nauka i umetnosti), knjiga 155 (Beograd: Naučna knjižara, 1950); Marko Jačov, Spisi Kongregacije za propagandu vere u Rimu o Srbima 1622-1644, I, Zbornik za istoriju, jezik i književnost srpskog naroda, II. odeljenje, knjiga 26 (Beograd: SANU, 1986); Dušan Kašić, Otpor Marčanskoj uniji. Lepavinsko-severinska eparhija (Beograd: Pravoslavlje, 1986); Dušan Kašić, Srpski manastiri u Hrvatskoj i Slavoniji (Beograd: muzej Srpske pravoslavne crkve, 1996), 381-394; Zlatko Kudelić "Srpska pravoslavna crkva kao tema novijih istraživanja hrvatskih i inozemnih autora”, Časopis za suvremenu povijest 29 (1997), br. 1: 157-176; Zlatko Kudelić, "Srpska pravoslavna crkva u djelima hrvatskih i inozemnih autora između dva svjetska rata”, Časopis za suvremenu povijest 30 (1998), br. 3: 547-574; Kudelić, Marčanska biskupija, 34-49; Zlatko Kudelić, "Srpska pravoslavna crkva u Bosni i Hercegovini tijekom austrougarske vladavine u novijoj domaćoj i inozemnoj histriografiji”, Croatica Christiana periodica 32 (2008), br. 62: 29-62; Kudelić, “Čaplovičeva povijest Marčanske biskupije”, 160-174.

5 Janko Šimrak rođen je 29. svibnja 1883. u žumberačkim Šimrakima, a umro je 9. kolovoza 1946. u Križevcima. Teologiju je studirao u Zagrebu i Innsbrucku, gdje je i doktorirao 1910. godine, od 1925. godine bio je profesor istočnog bogoslovlja na Bogoslovskome fakultetu u Zagrebu. Bio je istaknuti član Hrvatske pučke stranke, narodni poslanik (1919. - 1923.) i ravnatelj dnevnika Hrvatska straža od 1921. do 1941. godine, a 1942. godine imenovan je biskupom grkokatoličke Križevačke eparhije (biskupije). Komunističke vlasti uhitile su ga 12. svibnja 1945, a 10. srpnja pušten je na slobodu i protiv njega su odbačene optužbe, ali su ga u poslijeratnom razdoblju neki povjesničari prozivali zbog navodne uloge u nasilnom prekrštavanju Srba u vrijeme Nezavisne Države Hrvatske. O razlozima zbog kojih nije spominjan u historiografiji Vojne krajine u Hrvatskoj može se zasad samo nagađati, ali znakovito je da Radonićeva i Gujićeva djela nisu doživjela sudbinu Šimrakovih u novoj Jugoslaviji, iako su, kao i poznati Viktor Novak, bili potpisnici Apela srpskom narodu iz kolovoza 1941. godine kojime je osuđen ustanak u Srbiji i narod pozvan da poštuje novu vlast i poredak. Štoviše, Radonić je u svom poznatom djelu o odnosu Rimske kurije s južnoslavenskim zemljama citirao i arhivsko gradivo koje je objavio Šimrak, a neke isprave iz njegove knjige objavio je i M. Jačov. Opširnije: Janko Šimrak, "Povijest Marčansko-Svidničke eparhije i crkvene unije u Jugoslavenskim zemljama", Bogoslovska smotra 12 (1924), br. 1: 64-81; br. 2: 160-187; br. 3: 286-311; br. 4: 412-446; Janko Šimrak, "Marčansko-Svidnička eparhija za vrijeme vladika Gabre i Vasilija Predojevića i Save Stanislavića”, Bogoslovska smotra 13 (1925), br. 1: 33-55; Janko Šimrak, "Marčanska eparhija", Bogoslovska smotra 18 (1930), br. 1: 31-73; Bogoslovska smotra 19 (1931), br. 1: 17-50, br. 2: 147-190; Šimrak, De relationibus Slavorum Meridionalium, 1-20; Janko Šimrak, Borba za crkveno i vjersko jedinstvo (Apologija Pavla Zorčića) (Zagreb: Tiskara Narodne prosvjete, 1932); Janko Šimrak, Arsenije III. Crnojević i unija (Zagreb: Tiskara Narodne prosvjete, 1935); Janko Šimrak, "Jedanaesti Marčanski Vladika Grgur Vučinić (1707-1709)”, u: Spomenica grkokatolika Križevačke biskupije za 1936. godinu (Zagreb: Tiskara narodna prosvjete 1936), 97-111; Janko Šimrak, "Dvanaesti marčanski vladika Rafael Marković”, u: Spomenica grkokatolika Križevačke biskupije za 1936. godinu (Zagreb: Tiskara narodna prosvjete 1936), 112-166; Ivan Peklić, "Prilozi za biografiju dr. Janka Šimraka”, Marulić 29 (1996), br. 2: 335-346; br. 6: 1155-1163; 30 (1997), br. 2: 365-371; Zlatko Matijević, Slom politike katoličkog jugoslavenstva: Hrvatska pučka stranka u političkom životu 
sintezu o Marčanskoj biskupiji napisao je Josip Uhač još 1954. godine na talijanskom jeziku, koja je tek 1996. objavljena na hrvatskom, a kako je autor zaključke većinom temeljio na objavljenom gradivu i literaturi J. Šimraka, ponovio je i neke njegove teze, npr. o unionističkom pokretu koji da nije bio samo posljedica političkog približavanja srpskih patrijarha Jovana i Pajsija Rimskoj kuriji već i izraz njihove želje za crkvenim jedinstvom s Katoličkom crkvom, te poput Šimraka dokument koji nosi datum 25. ožujka, ali ne i godinu objavljivanja, interpretirao kao izvor koji govori o dva različita događaja - prihvaćanju unije u proljeće 1611. godine u Marči, koje se prema njemu dogodilo 24. ožujka, i kao odgovor Vlaha predstavnicima zagrebačkog biskupa Petra Domitrovića 1613. godine na pitanje o mogućem plaćanju crkvene desetine. Zaključivši da je prvi marčanski biskup Simeon mogao biti rezidencijalni biskup, Uhač je odlazak trojice njegovih nasljednika na posvećenje pećkom patrijarhu objasnio između ostalog i dobrim odnosima između Rima i pećkih patrijarha u prvoj polovici 17. stoljeća, a smjenjivanje i uhićenje biskupa Gabrijela Mijakića 1670. godine nazvao je primjerom prevladavanja političkih zahtjeva nad zahtjevima religioznog karaktera. Neuspjeh unije djelomično je pripisao i postupcima zagrebačkih biskupa i ponašanju Bečkog dvora nakon dolaska Arsenija III. Crnojevića u Monarhiju, a najdiskutabilniji autorov zaključak jest onaj da je Sveta Stolica branila samostalnost vlaške zajednice u Hrvatskoj jer nije objasnio što je podrazumijevao pod pojmom vlaške zajednice niti u čemu se njezina samostalnost očitovala ako su marčanski biskupi morali biti vikari zagrebačkih biskupa za vjernike istočnog obreda, što su i postali 1671. godine, kad je po želji Leopolda I. Rim biskupa Pavla Zorčića imenovao apostolskim vikarom za Vlahe u Zagrebačkoj biskupiji. ${ }^{6}$ Nakon Šimraka ova tema sve do kraja osamdesetih godina prošlog stoljeća gotovo da i nije privukla veću pozornost ni hrvatske niti inozemne historiografije kao posebna tema nego se rijetko pojavljivala u različitim sintezama povijesti Vojne krajine i sintezama povijesti Srpske pravoslavne crkve, a inozemni autori koji su se njome bavili oslanjali su se na šturu domaću i inozemnu historiografiju ili na radove starije generacije povjesničara. Jedini inozemni autor koji je tada pisao o Vojnoj krajini koristeći i Šimrakove radove bio je Rudolf Grulich, koji je 1982. godine objavio sažet, ali kvalitetan znanstveni rad o Marčanskoj biskupiji i habsburškoj crkvenoj politici u Krajini, u kojem nije ponavljao pogrešne podatke iz krajiške historiografije 19. stoljeća, karakteristične i za historiografiju u 20. stoljeću. ${ }^{7}$ Međutim, detaljnija istraživanja o ovoj temi tijekom 18. stoljeća su izostala, a većina

Kraljevine SHS (1919. -1929.) (Zagreb: Hrvatski institut za povijest, 1998); Filip Škiljan, "Vjerski prijelazi s pravoslavlja na rimokatoličku i grkokatoličku vjeroispovijest u Podravini između 1941. i 1945. godine", Podravina 15 (2016), br. 29: 168-179; Stipan Bunjevac, Izvorni dokumenti OZNE o biskupu dr. Janku Šimraku $i$ "prekrštavanju « Srba u NDH, http://www.pobijeni.info/userfiles/BiskupJankoSimrak. pdf, pristupljeno 20. 8. 2020.; https://uskok-sosice.hr/svjedocanstvo-dr-ervina-schustera-o-nadbiskupu-stepincu-i-biskupu-simraku/, pristupljeno 20. 8. 2020.

6 Josip Uhač, Marčanska biskupija (eparhija): neki povijesni-pravni pregledi (Zagreb: Glas Koncila, 1996), 12, 25, 40-42, 124.

7 Grulich je zaključio da je na krajiškom području pravoslavlje tolerirano i da je sa Simeonom Vratanjom zaživjela unijatska/grkokatolička hijerarhija sa sjedištem u Marči, a ukazao je i na neke razlike u interpretaciji J. Šimraka i srpske historiografije o počecima unije na području Žumberka. Opširnije: Rudolf Grulich, "Kirchliche Relikte der Militärgrenze”, u: Die Österreichische Militärgrenze. 
istraživača priklonila se mišljenju da je problem unije riješen s dolaskom Arsenija III. Crnojevića na područje Habsburške Monarhije i organiziranjem pravoslavne crkvene hijerarhije. Tako je habsburška crkvena politika u Krajini, a šire gledano i u Hrvatskoj tijekom prve polovice 18. stoljeća ostala slabije istražena, s prevladavajućom tezom starije historiografije o konstantnoj prokatoličkoj habsburškoj politici i isusovcima kao njezinim glavnim i najutjecajnijim nositeljima tijekom 17. i 18. stoljeća. Njezini zagovornici nisu razlikovali prijedloge pojedinih katoličkih biskupa ili pripadnika određenog crkvenog reda o mogućim načinima provođenja unije od konkretne habsburške crkvene politike u Krajini, koja u pravilu takve prijedloge nije prihvaćala, niti su primijetili da arhivsko gradivo donosi puno složeniju sliku od one uvriježene u znanstvenim krugovima, odnosno činjenicu da su grkokatolici/unijati gotovo potpuno iščezli s krajiškog područja do početka 18. stoljeća, što pokazuje izvješće zagrebačkog biskupa Emerika Esterházyja o Svidničkoj (Marčanskoj) biskupiji iz listopada 1711. prema kojem je unijatskom svidničkom/marčanskom biskupu tada bilo podređeno samo šest župa. ${ }^{8}$ Budući da su o ovoj temi radove objavljivali autori iz crkvenih krugova te domaći i inozemni autori sinteza hrvatske povijesti i povijesti Vojne krajine prvo ćemo se osvrnuti na novije radove autora iz Katoličke crkve, a nakon toga i na radove posvećene povijesti Vojne krajine i raznovrsne sinteze povijesti Hrvatske koje su u većoj ili manjoj mjeri spominjali i ovu temu.

Prva knjiga o ovoj temi koja se pojavila gotovo četvrt stoljeća nakon Radonićeve i Uhačeve knjige jest djelo N. Ikića iz 1989. godine, u kojemu je autor analizirao sadržaj i značenje pojma unije od utemeljenja Marčanske biskupije 1611. godine do utemeljenja grkokatoličke Križevačke eparhije 1777. godine. ${ }^{9}$ Autor je pozornost u prvome redu posvetio događajima do prvog desetljeća 18. stoljeća i okolnostima utemeljenja Križevačke grkokatoličke biskupije krajem tog stoljeća, dok razdoblje vladavine Jo-

Geschichte und Auswirkungen, ur. Gerhard Ernst (Regensburg: Verlag Lassleben, 1982), 34-39; Kudelić, “Čaplovičeva povijest Marčanske biskupije”, 160-168, 170-174.

$8 \quad$ Kudelić, Marčanska biskupija, 431-432. Esterházyjevo izvješće bečkoj nuncijaturi vidjeti u: $\mathrm{Hr}-$ vatska (dalje: HR) - Nadbiskupijski arhiv u Zagrebu, Zagreb (dalje: NAZ) - Ecclesiastica - sv. 8, dok. 366. Nasljednicima biskupa Simeona na marčanskoj biskupskoj stolici tijekom 17. i 18. stoljeća u Rimu i Beču je određivano različito jurisdikcijsko područje zbog inzistiranja zagrebačkih biskupa Benedikta Vinkovića, Petra Petretića i Martina Borkovića da marčanski biskupi mogu samo biti njihovi vikari za kršćane grčkog obreda u Zagrebačkoj biskupiji, a nikako samostalni biskupi. Zato je Rim od 1671. godine biskupima Pavlu i Marku Zorčiću, Izaiji Popoviću, Gabrijelu Turčinoviću i Rafaelu Markoviću ograničio jurisdikciju samo na Zagrebačku biskupiju, no biskupima Grguru Jugoviću (1707. - 1709.), Grguru Vučiniću (1727. - 1733.) i Teofilu Pašiću (1738. - 1746.) jurisdikciju je proširio na Hrvatsku i Slavoniju. Bečki dvor držao je marčanske (svidničke) biskupe "vlaškim” biskupima nadležnima za krajiško područje i njihovim jurisdikcijskim područjem tijekom 17. stoljeća pretežno držao Hrvatsko-slavonsku vojnu krajinu i područje Ugarske. U prvoj polovici 18. stoljeća Beč je biskupima Gabrijelu Turčinoviću (1700. - 1707.), Grguru Vučiniću (1727. - 1733.) i Teofilu Pašiću (1738. - 1746.) jurisdikciju proširio na cijelu Hrvatsku i Slavoniju, ali ne i Ugarsku, ali tijekom prve polovice 18. stoljeća stvarnu biskupsku vlast obnašali su samo na području Varaždinskog generalata i Žumberka. Opširnije: Kudelić, Marčanska biskupija, 352-354, 368-370, 379-380, 396-398, 427-432, 443-444, 455-456, 474-478.

$9 \quad$ Niko Ikić, “Der Begriff Union” im Entstehungsprozeß der unierten Diözese von Marča (Križevci,): eine ekklesiologisch-juridische Untersuchung auf Grund einer geschichtlichen Darlegung (St. Otilien: EOS-Verlag, 1989). 
sipa I., Karla VI. i većega dijela vladavine Marije Terezije nije analizirao. Ustvrdivši da početkom 17. stoljeća nije postojala organizirana pravoslavna crkva u Monarhiji Ikić je na temelju analize sadržaja isprave nadvojvode Ferdinanda izdane biskupu Simeonu 10. siječnja 1612. godine zaključio da je već tada vlaška unija zadobila državo-političku i pravnu dimenziju i da ju je nadvojvoda Ferdinand držao nečim normalnim i samo po sebi razumljivim. No, iznio je i dvojbenu tezu da se preporuka upućena Simeonu o iskorjenjivanju vjerskih zabluda i praznovjernih običaja protivnih učenju Katoličke crkve nije nužno odnosila na vjeroispovijest Simeonovih vjernika, to jest da se spominjanje praznovjernih vjerovanja nije nužno odnosilo na vjeroučenje nego da je time nadvojvoda Ferdinand samo ukazao na tradicionalne razlike, prije svega one u liturgijskom području, između novodoseljenih Vlaha i starosjedioca. Spomenutu ispravu od 25. ožujka, koju mnogi povjesničari, pozivajući se na Šimraka, ističu kao ispravu koja govori o prihvaćanju unije u Marči 24. ožujka 1611. iako godina njezinog nastanka nije poznata, Ikić je nazvao odgovorom na prethodno iznesene prijedloge zagrebačkoga biskupa Petra Domitrovića o sjedinjenju s Katoličkom crkvom i istaknuo da je unija bila rezultat prožimanja i teološko-eklezioloških i vanjskopolitičkih čimbenika. Naglasivši da su Vlasi prvenstveno strahovali od gubitka državne potpore, to jest socijalnih prava ako bi bez Ferdinandova znanja prihvatili zahtjeve zagrebačkoga biskupa Petra Domitrovića zaključio je da se iz spomenute isprave ne može ništa precizno reći o zahtjevima religijskog karaktera te je istaknuo da su pod potporom koju su spomenuli u ispravi Vlasi zapravo mislili i na slobodno izražavanje svoje vjere u smislu postojanja posebnoga obreda, koji je na tome području bio nešto sasvim novo. Uspoređujući okolnosti Simeonova posvećenja i potvrde u Rimu s uvjetima pod kojima su započele druge unije Ikić je ustvrdio da na tom području nikada nisu djelovali misionari Kongregacije za propagandu vjere i da se ne može govoriti o pritisku na prvoga biskupa Simeona jer su iza Vlaha stajali krajiški zapovjednici, a hrvatski staleži nisu na tome području imali nikakav utjecaj, dok su se Habsburgovci prema pitanju unije odnosili ovisno o političkoj procjeni njezine svrsishodnosti i donosili odluke koje su ponekad štetile uniji, a ponekad joj pogodovale. Prema njegovome mišljenju prvu šestoricu marčanskih biskupa ne bi trebalo opisivati kao nesjedinjene/pravoslavne jer u razdoblju između 1611. i 1670. godine nije postojala priznata pravoslavna episkopija, Habsburgovci tada nisu imenovali pravoslavne episkope u Hrvatskoj, a imenovani marčanski biskupi trebali su prvo ispovjediti katoličku vjeru i tražiti potvrdu i posvećenje u Rimu. No, istaknuo je i da se već u tome razdoblju počela razvijati nacionalna svijest i kod doseljenika i kod starosjedioca, koja je dugo bila prožeta i prikrivena crkvenom pripadnošću, ali su je potaknule političke, crkvene i socijalne napetosti, zbog čega je povijest sjedinjenja Vlaha s Katoličkom crkvom u Hrvatskoj prije nalikovala ratnoj nego misijskoj povijesti i postupno se pretvorila i u nacionalno pitanje. ${ }^{10}$ Posebnost Ikićeve studije jest teza o kristocentričnome shvaćanju crkvenog jedinstva početkom 17. stoljeća, utemeljenome prema njegovomu mišljenju na odredbama firentinskoga koncila, u kojemu nisu jako naglašavane razlike nego

10 Ikić, “Der Begriff Union”, 12, 40-42, 56, 124-132, 153-175, 181-184, 190-191, 205-214, 246-253. 
je postojao zajednički misterij Crkve, to jest vjerovanje obiju Crkvi da je Krist središte pretpostavljenoga jedinstva koje bi bilo ostvareno djelovanjem Duha Svetoga. Biskup Simeon i papa Pavao V. bili su uvjereni da će istočni kršćani preko zajedničke vjere i krštenja biti privučeni uniji, a to je prema ovome autoru ujedno pokazalo i prisutnost sakramentalnoga shvaćanja jedinstva kršćana početkom 17. stoljeća, koje je nestalo sredinom toga stoljeća djelovanjem zagrebačkih biskupa Benedikta Vinkovića i Petra Petretića, predstavnika ekskluzivističke teologije, koji su u prvi plan stavljali legalistički i pravni koncept unije i uniformno jedinstvo. Već spominjani odlazak nekih marčanskih biskupa na posvećenje u Peć (nakon što su imenovani u Beču) Ikić je držao potvrdom teze o kristocentričnosti, a iznio je dvojbenu tezu da je Rim priznao biskupska posvećenja nekih marčanskih biskupa u Peći, na primjer Maksima Predojevića i Gabrijela Mijakića (koji nije posvećen u Peći nego u Jašiju u Moldaviji, a iz Rima se vratio bez potvrde o posvećenju, op. Z. K.), jer da su tamo trebali poći samo zbog potvrde, ali ne zbog posvećenja, iako o tome ne postoje precizni podaci. Istaknuo je i da su cijelo to vrijeme Vlasi i predstavnici crkvene, svjetovne i vojne vlasti imali potpuno različite stavove o značenju unije jer su Vlasi preko nje nastojali steći društvene povlastice, Habsburgovci vojno ojačati, a Rim nametanjem pravnih normi utjecati na Vlahe. Ikić je kao zagovornike pretjerane latinizacije istaknuo ljubljanskog biskupa Tomasa Hrena, smederevskoga naslovnog biskupa Aloisa (pogrešno, bio je Albert!, op. Z. K.) Renđića i Rafaela Levakovića, štićenika i kandidata zagrebačkoga biskupa Benedikta Vinkovića za marčanskoga biskupa te napomenuo da je od sredine 17. stoljeća jurističko shvaćanje unije prevladalo ono sakramentalno s početka toga stoljeća, što je dovelo do udaljavanja istočnih od zapadne Crkve, čemu da su pridonijeli i zaključci Tridentskoga sabora. I ovaj je autor ponovio tezu o Mijakićevom smjenjivanju s biskupske stolice zbog sudjelovanja u Zrinsko-frankopanskoj uroti, a analizirajući prijedloge katoličkih dužnosnika o načinu provođenja unije pravoslavnih Vlaha s kraja 17. i početka 18. stoljeća (isusovac Ferenc Ravasz, kardinal Leopold Kolonić i senjski biskup Martin Brajković) zaključio je da je krajem 17. stoljeća prevagnula ideja unije koja je jedinstvo shvaćala kao uniformnost izraženu u pravnim normama i koja se približila pojmu rekatolizacije, odnosno da je postojala ekskluzivistička ekleziologija koja je međusobno udaljila Crkve i bila daleko od onog značenja unije koje je početkom 17. stoljeća imala u Hrvatskoj. ${ }^{11}$

Kraće tekstove o ovoj temi devedesetih godina objavili su i drugi autori koji su istraživali povijest Katoličke crkve u Hrvatskoj ili Zagrebačke nadbiskupije pa je M.

11 Ikić, “Der Begriff Union”, 210-213, 220, 236-237, 254-269, 274-277, 282-286; Kudelić, Marčanska biskupija, 319. Ikićeva studija sadrži i prijevode nekih ključnih isprava o počecima unije i biskupu Simeonu na njemački jezik, i to ispravu korintskog arhiepiskopa Kozme kojom Simeona imenuje pravoslavnim episkopom, ispravu pećkog patrijarha Jovana kojom imenuje Simeona "vratanijskim" episkopom, pismo ivanićkog župnika Martina Dobrovića zagrebačkome biskupu Petru Domitroviću koje mnogi povjesničari interpretiraju i kao izvor koji potvrđuje prihvaćanje unije u proljeće 1611. godine u Marči i kao izvor koji spominje pregovore predstavnika zagrebačkoga biskupa s Vlasima o plaćanju crkvene desetine, prijevod dvaju pisama gradačkoga nuncija Antonija de Pontea kardinalu Borgheseu iz 1611. godine te prijevod brevea pape Pavla V. izdanoga biskupu Simeonu u studenome 1611. godine. Prijevod istoga dokumenta na hrvatski jezik vidjeti u: Roksandić, Etnos, 72-73. 
Korade opisujući životopise zagrebačkih biskupa Petra Domitrovića, Benedikta Vinkovića i Petra Petretića spomenuo i njihovo djelovanje glede širenja unije na temelju poznatih radova i novih izvora. Ukazao je na neodrživost teze starije historiografije da je na početak unije djelomično utjecalo i navodno podrijetlo zagrebačkoga biskupa Petra Domitrovića iz uskočke obitelji ili obitelji istočnoga obreda jer je prema novim arhivskim podacima Petar Domitrović bio rođen u Hrvatskomu zagorju. Samo je djelomično prihvatio Šimrakov zaključak da je biskup Benedikt Vinković počinio mnoge pogreške u pitanju unije napomenuvši da su stvari bilo složenije jer su u sklopu tadašnjih shvaćanja sukobi bili neizbježni, te je ustvrdio da nisu jasni motivi koji su naveli Vinkovićeva suvremenika Maksima Predojevića na odlazak na posvećenje u Peć. ${ }^{12}$ Šturi prikaz povijesti Marčanske biskupije iznio je i A. Lukinović u povijesti Zagrebačke biskupije navevši da su Simeon i predstavnici Vlaha prihvatili uniju 26. ožujka 1611. godine u Marči te da je papa Pavao V. Simeona imenovao titularnim biskupom svidničkim jer je taj naslov značio da su marčanski biskupi prije bili apostolski vikari zagrebačkoga biskupa nego pravi rezidencijalni biskupi. Međutim, valja napomenuti da je svidnički naslov prvi dobio biskup Gabrijel Predojević 1642. godine, a u breveu pape Pavla V. nije navedeno da prvi marčanski biskup Simeon mora biti vikar zagrebačkoga biskupa nego su marčanski biskupi imenovani vikarima zagrebačkoga biskupa za kršćane grčkog obreda u Zagrebačkoj biskupiji tek od biskupa Pavla Zorčića (1671. - 1685.). Lukinović je napomenuo da se crkveno jedinstvo održalo iako su neki biskupi vrludali između Rima i pravoslavlja, a odgovornim za neuspjeh unije proglasio je Leopolda I., koji je tijekom Bečkoga rata sve vjernike istočnoga obreda, pravoslavce i grkokatolike, podvrgnuo jurisdikciji Arsenija III. Crnojevića. ${ }^{13}$

Arhivsko gradivo o dolasku Arsenija III. Crnojevića u Hrvatsku iz Nadbiskupijskoga arhiva u Zagrebu analizirao je A. Sekulić i upozorio na patrijarhovu ulogu "u širenju i učvršćenju ideje o srpsko-pravoslavnoj državi na hrvatskom narodnom i državnom području”. Prema njegovomu mišljenju grkokatolici su početkom 17. stoljeća u Hrvatskoj živjeli kao posebna vjerska zajednica kojoj je na čelu bio grkokatolički poglavar-vladika, a vjernici su s crkvenim poglavarima bili u sufraganskom odnosu prema zagrebačkim biskupima, što je dvojben zaključak s obzirom na činjenicu da petorica marčanska biskupa uopće nisu bila potvrđena u Rimu niti su ih kao odgovarajuće kandidate predlagali zagrebački biskupi nego ih je bez konzultacija sa zagrebačkim biskupima samo potvrdio Bečki dvor. I ovaj je autor zaključio da je unija u Marči prihvaćena 26. ožujka 1611. godine i bila je posljedica održavanja veza pećkoga patrijarha Jovana s papom Klementom VIII., te je neuspjeh unije uzrokovan djelovanjem

12 J. Šimrak bio je sklon mišljenju da je Domitrović rođen u Ivaniću na biskupskom dobru. Opširnije: J. Šimrak, “Povijest Marčansko-svidničke eparhije”, 177; Mijo Korade, “Petar Domitrović 1611-1628”, u: Zagrebački biskupi i nadbiskupi, ur. Franko Mirošević (Zagreb: Školska knjiga, 1995), 297-298, 300-301; Mijo Korade, “Benedikt Vinković 1637-1642”, u: Zagrebački biskupi i nadbiskupi, ur. Franko Mirošević (Zagreb: Školska knjiga, 1995), 321-322; Mijo Korade, “Petar Petretić 1647-1667”, u: Zagrebački biskupi i nadbiskupi, ur. Franko Mirošević (Zagreb: Školska knjiga, 1995), 337-339.

13 Andrija Lukinović, Zagreb-stoljetna biskupija (Zagreb: Glas koncila, 1995), 192-193. 
Arsenija III. Crnojevića, koji je iskoristio nejasnoće u dvorskim ispravama glede vjere i obreda i koristio poistovjećivanje vjere s obredom za širenje "srpskoga pravoslavlja" i podvrgavanje vjernika grčkoistočnoga obreda u Hrvatskoj svojoj vlasti. ${ }^{14}$

Unijom i Marčanskom biskupijom bavio se i J. Burić u knjizi o Senjskoj i Modruškoj biskupiji, čiji je tekst nastao na talijanskome jeziku mnogo prije nego što je objavljen na hrvatskome jeziku, a i on se djelomično temelji na Šimrakovim radovima. Kao razloge neuspjeha unije spomenuo je političke koncepcije habsburškoga dvora od Ferdinanda I. do Leopolda I. (1527. - 1705.) o protektoratu nad svim kršćanima pod turskom vlašću nakon što Osmanlije budu istjerani iz Europe, zbog kojih Bečki dvor nikada nije dosljedno zastupao politiku crkvene unije, zatim pritiske zagrebačkih biskupa da grkokatolički biskupi moraju biti njihovi vikari za kršćane grčkoga obreda, pa različito poimanje vjere i obreda kod katolika i pravoslavaca kao i djelovanje pravoslavnih kaluđera protiv unije, antagonizme između Vlaha i katolika utemeljene u različitome mentalitetu te borbu za održavanjem povlaštenoga položaja Vlaha, što se očitovalo u otporu plaćanju crkvene desetine i odbacivanju jurisdikcije katoličkih biskupa i vlastele. ${ }^{15} \mathrm{U}$ sažetome tekstu Fr. E. Hoška i S. Kovačića spomenuto je prihvaćanje unije “60.000 Vlaha i Srba” u proljeće 1611. godine u Marči koja da se održala sve do dolaska Arsenija III. Crnojevića u Hrvatsku i Ugarsku, a kojem je država podredila sve kršćane grčkoga obreda, što je on iskoristio da progoni grkokatolike. Prema ovim autorima unija nije uspjela zbog nepovjerenja između sjedinjenih/unijatskih biskupa i zagrebačkih biskupa, niskoga obrazovanja svećenstva koje je uniju prihvaćalo kao društvenu nuždu, zbog protivljenja jednog dijela pravoslavnih vjernika i svećenstva uniji te državne politike koja je iz praktičnih razloga pravoslavnim i grkokatoličkim krajišnicima dodijelila samoupravu i izazvala sukob s plemstvom i vlastelom. Neuspjeh unije na području Senjsko-modruške biskupije smatrali su posljedicom prijepora svidničkoga/marčanskoga biskupa Teofila Pašića sa senjsko-modruškim biskupom Benzonijem, koji je želio da sâm Pašić bude njegov generalni vikar, a neuspjeh unije u mletačkoj Dalmaciji objasnili su protivljenjem pravoslavnih kaluđera i katoličkih biskupa koji su tvrdili da u njihovim biskupijama mogu postojati dva različita obreda, ali ne i dvije jurisdikcije, bilo one pravoslavne ili grkokatoličke. Zaključili su da su grkokatolici gotovo nestali u Hrvatskoj zbog nepovjerenja katoličkih biskupa u sjedinjene vladike i zbog državne politike Habsburgovaca koji su srpskoga pravoslavnoga patrijarha priznali vjerskim i feudalnim poglavarom svih kršćana grčkoga obreda. ${ }^{16}$

Na Marčansku biskupiju i uniju u Hrvatskoj osvrnuo se i J. Kolarić u knjizi o ekumenskoj trilogiji, sažeto opisavši zbivanja od utemeljenja Marčanske biskupije do osniv-

14 Ante Sekulić, “Tragovi Arsenija III. Crnojevića u Nadbiskupijskom arhivu u Zagrebu”, Tkalčić (1998), br. 2: 105-127.

15 Josip Burić, Biskupije Senjska i Modruška u XVIII. stoljeću (Gospić; Zagreb: Kršćanska sadašnjost, 2002), 174-175, 188-204.

16 Franjo Emanuel Hoško, Slavko Kovačić, “Crkva u vrijeme katoličke obnove: Marčanska unija i neki slični pokušaji”, u: Hrvatska i Europa. Kultura, znanost i umjetnost, sv. III: Barok i prosvjetiteljstvo (XVII-XVIII. stoljeće), ur. Ivan Golub (Zagreb: HAZU; Školska knjiga 2003), 165-186. 
anja Križevačke grkokatoličke biskupije. I ovdje nalazimo tezu o počecima unije kao rezultatu unijatskoga pokreta početkom 17. stoljeća, koju su potaknuli i međusobni kontakti pravoslavnih doseljenika s katoličkim starosjediocima, a unija je djelomično bila potaknuta navodnim pravoslavnim podrijetlom zagrebačkog biskupa Petra Domitrovića iako ta teza nije više održiva nakon Koradeova podatka o Domitrovićevom porijeklu. Međutim, nejasno je na temelju čega je autor ustvrdio da su stotinu i više godina prije Arsenija III. Crnojevića u Hrvatsku došli kršćani grčkoistočnoga obreda i 1622. godine osnovali grkokatoličku biskupiju ako je unijatska Marčanska biskupija formalno utemeljena 1611. godine sa sjedištem u samostanu sv. Mihaela Arkanđela u Marči. Zaključivši da se ni marčanski biskup Izaija Popović ni njegovi nasljednici nisu pokorili Arseniju III. Crnojeviću kao crkvenom autoritetu, kao krivca za nestanak unije u manastiru Gomirju i na cijelom području od Kupe do mora spomenuo je Atanazija Ljubovića, dabrobosanskoga mitropolita koji je došao tijekom Bečkoga rata u manastir Komogovinu kod Kostajnice i bio potvrđen za pravoslavnoga episkopa za područje Karlovačkoga generalata 1708. godine i koji je po dolasku u manastir Komogovinu protjerao grkokatoličke kaluđere iz manastira pa su se sklonili u Marču. ${ }^{17}$ I tekst F. Šanjeka u sintezi povijesti Hrvata sadrži tezu o pojavi unionističkoga pokreta krajem 16. stoljeća u istočnoj Europi, utemeljenog na Firentinskom saboru 1439. godine, čiji je rezultat bila i Brest-litovska unija. Prema njemu dio pravoslavaca u Banskoj Hrvatskoj, "uskoka" i "prebjega" doseljenih s turskih područja na teritorij Karlovačkoga i Varaždinskoga generalata, prihvatio je uniju 1611. godine i za njih je uspostavljena Svidničko-marčanska biskupija, ali treba napomenuti da prilikom imenovanja prvoga biskupa Simeona u Rimu novoj grkokatoličkoj biskupiji nije određeno ime nego ju je "svidničkom" nazvao Bečki dvor tek 1642. godine nakon spora s Rimom o naslovu koji bi trebao dobiti novi “vlaški”/marčanski biskup. Šanjek nije analizirao događaje od Simeonove smrti do izbora biskupa Gabrijela Mijakića 1663. godine, nego je najveći dio teksta posvetio upravo Mijakićevu životu opisavši ga kao oduševljenoga pristalicu Zrinsko-frankopanske urote, zbog koje je i osuđen na doživotni zatvor, a poput J. Šimraka i on je koristio pojam "uskoci”, a ne "Vlasi"za pravoslavne krajišnike iako je potonji naziv u izvorima zastupljeniji. Mijakićev motiv za suradnju sa Zrinskim i Frankopanom objasnio je nadom da će se uz njihovu pomoć uskoci osloboditi nasilja koje su njemački časnici provodili u Krajini, naglasivši da je Mijakić držao bana Petra Zrinskoga zaštitnikom pred pokušajima zagrebačkih biskupa Petra Petretića i Martina Borkovića da marčanske biskupe pretvore u vikare za kršćane grčkoga obreda u Zagrebačkoj biskupiji ili čak ukinu Marčansku biskupiju, što je kod "uskoka" izazvalo bojazan da će postati i kmetovi i izgubiti pravo na svoj istočni obred. Mijakićevo prihvaćanje položaja vikara zagrebačkoga biskupa za kršćane grčkoga obreda ocijenio je pokušajem iskupljenja za sudjelovanje u uroti sa

17 Juraj Kolarić, Ekumenska trilogija: istočni kršćani, pravoslavni, protestanti (Zagreb: Prometej, 2005), 396-398, 410. Tezu o uskočkom podrijetlu Petra Domitrovića prije Kolarića spomenuli su još F. Hammerl i R. Grulich 1982. godine, ali je M. Korade 1995. godine upozorio da je Domitrović bio rodom iz Hrvatskog zagorja. Opširnije: Grulich, "Kirchliche Relikte der Militärgrenze”, 34-39; Korade, "Petar Domitrović 1611-1628”, 297-298. 
Zrinskim i Frankopanom, što je dvojbena teza jer se Mijakić odrekao pećkoga patrijarha prisegom u Beču još u jesen 1663. godine i kao duhovne poglavare prihvatio rimskoga papu, ostrogonskoga i kaločkoga nadbiskupa te prihvatio položaj vikara zagrebačkoga biskupa, ali nije poznato da je već tada s Nikolom i Petrom Zrinskim i Franom Krstom Frankopanom uopće razgovarao o ikakvome sudjelovanju u uroti. Dvojben je i zaključak da je Mijakić uz pomoć Petra Zrinskoga htio osloboditi krajišnike od nasilja njemačkih časnika i onemogućiti ukidanje njegove biskupije ili njegovo pretvaranje u vikara zagrebačkoga biskupa jer nije jasno kako je Petar Zrinski mogao utjecati na odluke rimske kurije ili Bečkoga dvora glede imenovanja biskupa ili ukidanja određene biskupije. Isto tako treba primijetiti da u historiografiji nije poznata isprava koja bi potvrdila da je Rim Mijakiću namjeravao dodijeliti jurisdikciju nad svim vjernicima istočnoga obreda od Drave do mora jer je taj prostor kao jurisdikcijsko područje marčanskim biskupima do Pavla Zorčića određivao Bečki dvor ne obazirući se na prigovore zagrebačkih biskupa da bi marčanski biskupi morali biti njihovi vikari. No, u slučaju Pavla Zorčića Rimska kurija bila je spremna uvažiti te prigovore, ali ga je ipak na Leopoldov zahtjev imenovala apostolskim vikarom samo za Vlahe u Zagrebačkoj biskupiji jer je time simbolično trebalo pokazati da su Vlasi s područja Zagrebačke biskupije bili podređeni Leopoldu I. kao vladaru, a ne zagrebačkome biskupu. ${ }^{18}$

Marčansku biskupiju spomenuo je i teolog E. Suttner u tekstu o "Grcima” pod Habsburgovcima prije 1683. godine oslanjajući se na Ikićevo djelo i na isusovca N. Nillesa iz 19. stoljeća. Početke unije povezao je sa Saborom u Brucku na Muri 1578. godine, gdje je prema njegovome mišljenju uskocima koji su se iz Osmanskoga Carstva naselili krajem 16. i tijekom 17. stoljeća u habsburški dio Ugarske odobreno ispovijedanje pravoslavne vjere, održavanje njihove tradicije i veza s Pećkom patrijaršijom iako ovu tvrdnju nije potkrijepio nikakvim konkretnim podacima iz arhivskoga gradiva. Njegovu tezu o Marčanskoj biskupiji kao jednoj manjoj dijecezi i marčanskome samostanu kao duhovnome središtu uskoka i sjedištu jedne manje biskupije potrebno je ispraviti jer je jurisdikcijsko područje prvoga biskupa Simeona obuhvaćalo Ugarsku, Hrvatsku, Slavoniju i Žumberak, koji je crkveno bio podređen Akvilejskoj patrijaršiji, ali iako su tijekom 17. i 18. stoljeća zbog spora oko patronatskoga prava Beča i Rima nekim marčanskim biskupima kao jurisdikcijsko područje određivane Hrvatska i Slavonija, a nekima samo Zagrebačka biskupija, no autor nije obrazložio razloge te promjene. Nadalje, dvojben je i njegov zaključak da su doseljeni istočni kršćani prihvatili uniju s “državnom crkvom Austrije” jer je biskup Simeon prihvatio uniju s Katoličkom crkvom, a ne s nekom nepostojećom austrijskom državnom crkvom neovisnom o Rimu, a tvrdnji da je unija u početku bila prihvatljiva jer nije pretpostavljala ni promjenu crkvene baštine uskoka niti prekidanje zajedništva $\mathrm{s}$ patrijarsima u Peći tako dugo dok su to odnosi Habsburgovaca i Osmanlija dopuštali, proturječe podaci da je nadvojvoda Ferdinand u proljeće 1611. godine biskupu Sime-

18 Franjo Šanjek, "Unijatska crkva i pravoslavlje u Hrvatskoj”, u: Povijest Hrvata. Druga knjiga: od kraja 15. st. do kraja prvog svjetskog rata, ur. Mirko Valentić, Lovorka Čoralić (Zagreb: Školska knjiga 2005), 183-185; Kudelić, Marčanska biskupija, 354. 
onu dodijelio patent kojim ga je priznao biskupom pod uvjetom da ukloni praznovjerna vjerovanja i zablude među vjernicima, koji su protivni učenju Katoličke crkve, te da je kardinal R. Bellarmin napomenuo kako je prvi marčanski biskup Simeon uniju prihvatio prema odredbama koje je Katolička crkva propisala za "Grke", to jest pravoslavne kršćane. Arhivsko gradivo ne potvrđuje ni autorovu tezu da su odnosi između Habsburške Monarhije i Osmanskoga Carstva utjecali na zajedništvo s pećkim patrijarsima i očuvanje crkvene baštine uskoka, nego otkriva da su tijekom 17. stoljeća pravoslavni Vlasi i njihovo svećenstvo stalno održavali veze s pećkim patrijarsima i neometano prelazili državnu granicu bez obzira na odnose dviju država, a egzarsi pećkih patrijarha dolazili su na krajiško područje i u ime pećkoga patrijarha među Vlasima pobirali crkveni porez i provjeravali prilike među njima i njihovim svećenstvom, djelujući protiv unije. Protiv toga jedino su protestirali zagrebački biskupi Benedikt Vinković i Petar Petretić vidjevši u tome i sigurnosni problem, to jest mogućnost špijuniranja za Osmanlije i prijetnju za Katoličku crkvu zbog širenja pravoslavlja u Krajini, a unija je bila unutarnje političko pitanje Habsburške Monarhije, to jest pitanje odnosa Bečkoga dvora prema njoj, koji je pod utjecajem krajiških vojnih predstavnika o opasnosti od krajiških nemira odbijao poduzeti konkretnije mjere. Suttner nije izravno spomenuo ni Vojnu krajinu kao područje na koje se pitanje unije odnosilo ni vlaško pitanje, koje se pojavilo istovremeno, nego je kao bitan neteološki motiv za uniju spomenuo lakše integriranje bjegunaca u novu domovinu i brigu njihovih crkvenih predstavnika da ih uklope u privredni i društveni život. I autorove teze da je bjeguncima u prilog išlo to što su posjedovni odnosi u novoj domovini vodili bliskim privrednim vezama marčanskih biskupa s kudikamo većom hrvatskom crkvom (!), a posebno Zagrebačkom biskupijom, i da je crkveno zajedništvo manje Marčanske biskupije preko spomenute državne (!) crkve Habsburške Monarhije s cijelom zapadnom Crkvom značilo dobrodošlu socijalnu zaštitu za bjegunce dvojbene su jer je prema arhivskome gradivu jedan od razloga neuspjeha unije bilo njezino poistovjećivanje s pokmećivanjem, a sve do sedamdesetih godina 17. stoljeća trajali su bezuspješni pokušaji zagrebačkih biskupa da im Vlasi s posjeda Zagrebačke biskupije, koji su postali dio Vojne krajine, plaćaju barem simboličnu naknadu za uživanje tih posjeda, što su odbijali svi krajišnici, a ne samo pravoslavni Vlasi, vidjevši u tome opasnost od njihovoga pretvaranja u podložnike zagrebačkih biskupa ili plemstva. ${ }^{19}$

Zaključci navedenih autora pokazuju velik utjecaj Šimrakovih teza o unijatskom pokretu kao motivu za uniju u Hrvatskoj i o općemu prihvaćanju unije tijekom prve polovice 17. stoljeća i sudjelovanju Gabrijela Mijakića u uroti kao razlog njegova uhićenja te o propasti unijatskoga pokreta s pojavom pećkoga patrijarha Arsenija III. Crnojevića u Monarhiji, uz čiji dolazak mnogi povjesničari navode pretjerano veliki broj osoba iako je u historiografiji već dugo isticano da je često spominjani broj od preko trideset tisuća obitelji netočan. ${ }^{20}$ Zanimljivo je da osim N. Ikića nitko od autora

19 Suttner, Staaten und Kirchen, 352-353; Uhač, Marčanska biskupija, 25-27; Kudelić, Marčanska biskupija, 191-216, 269-274.

20 D. Popović je naveo da je s patrijarhom Arsenijem III. Crnojevićem došlo između 60.000 i 70.000 osoba, N. Malcolm je upozorio da je patrijarh Crnojević u svojim pismima spomenuo 30.000, odnosno 
koji govore o prihvaćanju unije u proljeće 1611. godine u Marči nije kao izvor koji bi potvrdio Simeonovo prihvaćanje unije spomenuo ispravu nadvojvode Ferdinanda izdanu 10. siječnja 1612. godine, u kojoj jasno stoji da je Ferdinand Simeonu Vratanji 23. ožujka 1611. dodijelio patent kao biskupu "Vlaha i Rasciana" pod uvjetom da među vjernicima iskorijeni zablude i praznovjerna vjerovanja suprotna Katoličkoj crkvi. Taj podatak uopće ne sadrži isprava od 25. ožujka, koju većina istraživača navodi kao ispravu koja govori o prihvaćanju unije u proljeće 1611. godine iako u toj ispravi godina njezinoga nastanka nije navedena, a unija se uopće izričito ne navodi. Kod nekih autora primjetni su i kontradiktorni zaključci o habsburškoj vjerskoj politici jer, dok s jedne strane ističu da su Habsburgovci svojom crkvenom politikom uzrokovali neuspjeh unije dodjeljujući povlastice Arseniju III. Crnojeviću, s druge zaključuju da je unijatska crkva u Banskoj Hrvatskoj do kraja 18. stoljeća opstala baš zahvaljujući zaštiti austrijskih careva, koji su je podupirali. Međutim, unijati/grkokatolici održali

40.000 osoba u seobi, što je prihvatio i B. Anzulović, S. Žuljić je prema Enciklopediji Jugoslavije naveo "više od 30.000 Srba", a i N. Spannenberger i J. Burkhardt spomenuli su 60.000 osoba. Iako je Z. Mirdita naglasio da je pretjerani broj doseljenih srpskih obitelji prvi iznio Vuk Stefanović Karadžić, koji je najprije spomenuo 27.000, a 1849. godine 37.000 obitelji koje da su prešle u Monarhiju neki autori još uvijek ponavljaju taj broj: J. Uhač je naveo čak pola milijuna Srba, M. Tanner, T. Judah i J. Kolarić govore o 30.000 obitelji, Z. Velagić o 37.000 , W. O’Reilly spominje 40.000 obitelji, T. M. Bohn 30.00035.000 srpskih obitelji, a K.X. Havadi-Nagy govori o 150.000-200.000 pridošlih Srba. Opširnije: Marcus Tanner, Hrvatska-država stvorena u ratu (Zagreb: Barbat; Hrvatska sveučilišna naklada; Hrvatski institut za povijest, 1999); Nicolaus Nilles, Symbolae ad illustrandam historiam Ecclesiae orientalis in terris coronae Sancti Stephani, I. (Oeniponte: Typis et sumptibus Feliciani Rauch, 1885), 27-29; Radoslav Grujić, Kako se postupalo sa srpskim molbama na dvoru cesara Austrijskog poslednje godine života patrijarha Arsenija III. Crnojevića (Novi Sad: Matica srpska, 1906) 12, 46; Dušan Popović, Velika seoba Srba 1690: Srbi seljaci i plemići (Beograd: Srpska književna zadruga, 1954), 41; Noel Malcolm, Kosovo. A Short History (New York: NYU Press, 1998), 160-163; Uhač, Marčanska biskupija,7; Tanner, Hrvatska-država stvorena u ratu, 71; Gerhard Seewann, "Migrationen in Südosteuropa als Voraussetzung für die neuzeitliche West-Ostwanderung", u: Matthias Beer und Dittmar Dahlmann, Migration nach Ostund Südosteuropa. vom 18. bis zum Beginn des 19. Jahrhunderts. Ursachen, Formen, Verlauf, Ergebnis (Schriftenreihe des Instituts für donauschwäbische Geschichte und Landeskunde, Band 4) (Stuttgart: Franz Steiner Verlag, 1999), 95-100; Tim Judah, The Serbs: History, Myth and the Destruction of Yugoslavia (New Haven; London: Yale University Press, 2000), 46; Zoran Velagić, “The Croatian Author at the Frontier of Catholicism and Orthodoxy in Croatia", u: Frontiers of Faith. Religious Exchange and the Constitution or Religious Identities 1400-1750, ur. Eszter Andor, István György Tóth (Budimpešta: Central European University; European Science Foundation 2001), 97; Kolarić, Ekumenska trilogija, 348; Zef Mirdita, Vlasi u historiografiji (Zagreb: Hrvatski institut za povijest, 2004) 146, bilj. 17; Josef Wolf, Entwicklung der ethnische Struktur des Banats 1890-1992 (Atlas Ost-Südosteuropa. Aktuelle Karten zu Ökologie, Bevölkerung und Wirtschaft) (Beč: Östereichische Ost und Südosteuropa-Institut, 2004); Johannes Burkhardt, Vollendung und Neuorientierung des frühmodernen Reiches 1648-1763 (Stuttgart: Klett.Cota 2006), 153-156; William O’Reilly, "Border, Buffer and Bulwark. The Historiography of Military Frontier, 1521-1881", u: Frontiers and the Writing of history, ur. Steven G. Ellis, Raingard Eßer (Hanover: Wehrhahn, 2006), 234; Thomas M. Bohn, "Vampirismus in Österreich und Preussen. Von der Entdeckung einer Seuche zum Narrativ der Gegenkolonisation”, Jahrbücher für Geschichte Osteuropas 56 (2008), br. 2: 163; Norbert Spannenberger, "Immigrationspolitik und interkonfessionelle Zusammenleben im 18. Jahrhundert in Süd-Transdanubien”, u: Kirchen als integrationsfaktor für die Migranten im Südosten der Habsburger Monarchie im 18. Jahrhundert, ur. Rainer Bendel- , Norbert Spannenberger (Berlin: LIT Verlag, 2010), 31; Kinga Xénia Havadi-Nagy, Die Slawonische und Banater Militärgrenze. Kriegserfahrungen und räumliche Mobilität (Cluj-Napoca; Academia Românâ Centrul de Studii Transilvane, 2010), 62; Branimir Anzulović, Mit o nebeskoj Srbiji. Polazište osvajačkih ratova i zločina u 20. stoljeću (Zagreb: Večernji posebni proizvodi, 2011), 98. 
su se i na Žumberku, koji se nalazio u sastavu Vojne krajine, a preseljenje sjedišta biskupije iz Marče prvo u Pribić, pa zatim u Križevce, izvan područja Vojne krajine, pokazalo je neuspjeh planova o uniji pravoslavnih krajišnika s Katoličkom crkvom. Neki autori iz Katoličke crkve iznosili su i dosta kritične stavove o prijedlozima zagrebačkih biskupa Benedikta Vinkovića, Petra Petretića i Martina Borkovića glede provođenja unije te isticali da se unija nesmetano razvijala sve do dolaska Arsenija III. Crnojevića iako izvješća zagrebačkih i marčanskih biskupa te krajiških zapovjednika prikazuju kudikamo složeniju situaciju, ali se na njihov sadržaj zagovornici teze o općem prihvaćanju unije nisu detaljnije osvrnuli. ${ }^{21}$

I u historiografiji Hrvatsko-slavonske vojne krajine kao i domaćim i inozemnim sintezama hrvatske povijesti o crkvenoj uniji prisutni su zaključci preuzeti od inozemnih autora, posebno austrijske historiografije iz druge polovice 19. stoljeća, kao i različito poimanje značenja pojma unije i uvjeta postavljanih za njezino prihvaćanje. Iako arhivsko gradivo kao ključne odredbe za sklapanje unije jasno navodi odredbe IV. Lateranskoga koncila, zatim Firentinskoga koncila iz 1439. godine, te odredbu pape Pia IV. iz 1563. godine o podložnosti biskupa grčkog obreda latinskim biskupima u čijim su se biskupijama nalazili, a na koju su se pozivali i zagrebački biskupi, u dijelu historiografije uvriježena je interpretacija kako je za uniju bilo potrebno samo prihvaćanje papinskoga autoriteta, ali ne i prilagođavanje vjerovanja, obreda i običaja onih koji su željeli uniju katoličkome nauku te teza o razlikovanju eklezijalne unije, koja da je pretpostavljala institucionalne promjene, od religijske unije, koja je pretpostavljala prihvaćanje katoličkoga nauka, ali i održavanje posebnoga crkvenog obreda. No, utemeljenost ovih teza čini se upitnom uzmu li se u obzir razna izvješća koja naglašavaju različito poimanje obreda i vjere kod katolika i pravoslavaca u tom vremenu, zbog čega su npr. zagrebački biskupi u 17. stoljeću prilikom izbora novih marčanskih biskupa kao jedan od uvjeta za njihovo imenovanje isticali baš prilagođavanje istočnoga obreda i običaja nauku Katoličke crkve. Kao što je već rečeno, nadvojvoda Ferdinand dodijelio je Simeonu Vratanji 23. ožujka 1611. patent kao biskupu "Vlaha i Rasciana" pod uvjetom da među vjernicima iskorijeni zablude i praznovjerna vjerovanja suprotna Katoličkoj crkvi, a podaci o marčanskim biskupima između 1630. i 1663. godine pokazuju da su oni u Beču prisezali kao unijati pod jasno određenim uvjetima ili su obećavali da će ih ispuniti nakon službenoga imenovanja na Dvoru, kao što je to bio slučaj s Gabrijelom Mijakićem. ${ }^{22}$

21 Šimrak, De relationibus Slavorum Meridionalium, 35; Ikić, "Der Begriff Union”, 158; Kudelić, Marčanska biskupija, 163-171.

22 Teodor Pompiliu, "The confessional identity of the Transylvanian Greek Catholic Church", u: Confessional Identity in East-Central Europe, ur. Maria Craciun, Ovidiu Ghitta, Graeme Murdock (Farnham: Ashgate, 2002), 168-169; Kudelić, Marčanska biskupija, 33-57, 145-157, 170-171, 189-190, 231-252, 265, 274-275, 318; Josef Macha, Ecclesiastical Unification. A Theoretical Framework Togerher With Case Studies From the History of Latin-Byzantine Relations (Roma: Pontificum Institutum Orientalium Studiorum, 1974); Howard Louthan, "Multiconfesionalism in Central Europe", u: A Companion to Multiconfesionalism in the Early Modern World, ur. Thomas Max Safely (Leiden; Boston: Brill, 2011), 379-380. Louthan je unijatsku crkvu nazvao jednom od dvije varijante pravoslavlja (?!) među Rusinima 
Historiografija 19. stoljeća kao izvor podataka za religijsku i crkvenu povijest na krajiškomu području vrlo je nepouzdana i sadrži zaključke koje ne potvrđuju izvorne isprave, a postali su temelj za vrlo popularnu tezu o stalnoj represivnoj vjerskoj politici i zajedničkome unijatskom pritisku državnih i crkvenih vlasti Habsburške Monarhije na pravoslavne krajišnike i o isusovcima kao nositeljima nasilnog unijaćenja, a koji su bez ograničenja mogli djelovali na krajiškom području. Pod utjecajem starije historiografije ova teza je i danas dominantna u inozemnoj historiografiji, posebno zahvaljujući poznatomu Rothenbergovom djelu o Vojnoj krajini, koji je na temelju austrijske historiografije iz 19. stoljeća isusovce proglasio glavnim zagovornicima i promicateljima unije u Krajini zajedno s krajiškim vojnim zapovjednicima. Njegove zaključke ponavljali su mnogi znanstvenici iako arhivsko gradivo pokazuje da su se isusovci na krajiškomu području pojavljivali samo povremeno i uz dopuštenje vojnih vlasti i izbjegavali rasprave o uniji, a da je Bečki dvor odbio prijedloge nekih isusovaca koji su podržavali stavove zagrebačkih biskupa o načinu provođenja unije. ${ }^{23}$ Noviji primjer opisa habsburške vjerske politike i odnosa prema grkokatolicima i pravoslavcima temeljen na literaturi iz 19. stoljeća jest Kaserova knjiga iz 1997. godine, koja sadrži pogrešne Rothenbergove, Csaplovicseve i Vaničekove podatke o povijesti Marčanske biskupije i uniji. Kaser je ponovio Rothenbergovu tezu o unijatskome pokretu koji je poticala vojna uprava u Varaždinskome generalatu u 17. stoljeću i pod čijim da je pritiskom Simeon Vratanja prihvatio uniju, navevši da je rimski papa imenovao Simeona "grko(pravoslavno)katoličkim biskupom”(sic!), ali značenje ovoga pojma nije detaljnije objasnio. Kao karakterističan običaj za Marčansku biskupiju tijekom prve polovice 17. stoljeća naveo je običaj da sami krajišnici biraju biskupe koji su formalno izjavljivali da su unijati, ali i dalje ostajali pravoslavni te je ponovio već spominjani podatak da je na Saboru u Brucku na Muri određena godišnja svota koja se morala isplaćivati marčanskom vladiki. Taj podatak preuzeo je iz historiografije 19. stoljeća, a njegovu utemeljenost tek bi morala potvrditi detaljnija istraživanja, to jest tek bi trebalo utvrditi je li se u to vrijeme pravoslavni episkop uopće nalazio u Marči, odnosno kada ga je i tko od predstavnika habsburških vlasti službeno imenovao i potvrdio. Njegov opis povijesti Marčanske biskupije od biskupovanja Pavla Zorčića do početka vladavine Marije Terezije temelji se na pogrešnim Csaplovicsim, Vaničekovim i Rothenbergovim podatcima, koji je, na primjer naveo da je Pavao Zorčić pobjegao u Zagreb i ondje umro, iako je on prema izvorima umro u Marči u siječnju 1685. godine. Ponovio je tezu o isusovcima koji su nametali uniju kada su se pojavili u Zagrebu 1673. godine (!?), što je netočno jer su isusovci stigli u Zagreb 1606. godine i iduće godine otvorili gimnaziju, ali je ova teza u stranoj historiografiji općeprihvaćena od druge polovice 19. stoljeća te je krivo naveo da je Svidnica bila novo sjedište grkoka-

i naveo da su u slučaju Brest-litovske unije biskupi prihvatili rimsko prvenstvo, ali da su sačuvali pravoslavni obred (?!).

23 Autori iz 19. stoljeća čije su netočne zaključke o habsburškoj vjerskoj politici u Krajini nekritički preuzimali i ponavljali povjesničari u 20. stoljeću su J. Bartenstein, J. Csaplovics, A. Stojačković, K. Czoernig, Emil Picot, J. H. Schwicker i F. Vaniček. Opširnije: Gunther Erich Rothenberg, The Austrian Military Border in Croatia, 1522-1747 (Urbana: University of Illinois Press, 1960); Kudelić, "Čaplovičeva povijest Marčanske biskupije”, 143-160, 166-169. 
toličke biskupije jer se zapravo radilo o imenu kojim je Marčansku biskupiju nazivao Bečki dvor, a nikako o nekome novom sjedištu biskupije jer je marčanski samostan Sv. Mihaela Arkanđela bio sjedište biskupije do 1739. godine kada je spaljen. Kaser je spomenuo navodni pritisak na pravoslavne kaluđere i krajišnike tijekom biskupovanja Rafaela Markovića i prisilno nametanje brakova krajišnika s katolkinjama kako bi postali unijati, osobito u Karlovačkome generalatu, zaključivši da je unijatski pokret u Varaždinskome generalatu prestao postojati nakon krajiških pobuna 1715. i 1718. - 1719. godine. Te zaključke preuzeo je iz nepouzdane Vaničekove knjige, koji na primjer uopće ne spominje Markovićevo unijatsko djelovanje, a djelomično se radi i o predaji koju je iz historiografije 19. stoljeća nekritički preuzela i suvremena historiografija. Nadalje, pogrešno je naveo da je Lepavinsko-severinska eparhija utemeljena 1737. godine umjesto 1734. godine, a utemeljenje grkokatoličke Križevačke biskupije 1777. godine nazvao je dokazom da vladalačka kuća nije prestala podupirati unijatski pokret, ne objasnivši tko ga je u tome razdoblju predstavljao i kao takav pokrenuo ako je prethodno zaključio da je unijatski pokret u Krajini prestao postojati nakon krajiških pobuna između 1715. i 1719. godine, za biskupovanja Rafaela Markovića. ${ }^{24}$ Neki od ovih dvojbenih zaključaka prisutni su u raznim oblicima i u inozemnoj literaturi pa je $\mathrm{O}$. Ghitta ponovio tezu o latinskoj hijerarhiji i isusovcima kao nositeljima i organizatorima unijaćenja u Hrvatskoj, a M. Tanner u sintezi o povijesti Hrvatske zaključio da su sporovi između pravoslavnih krajišnika i Sabora početkom 18. stoljeća prerasli u politiku rasne i vjerske netolerancije, dok je J. Fine u knjizi o značenju pojma etniciteta u Hrvatskoj kroz srednji i rani novi vijek na temelju starije literature govorio o katoličkim ofenzivama u Krajini koje su smjerale ukidanju slobode vjeroispovijesti za pravoslavne krajišnike. Oba autora pozvala su se na Rothenbergovu knjigu i kao primjer istaknuli odluku bečkog Dvora o vraćanju marčanskoga samostana i crkve grkokatolicima iako je ona donesena na temelju presude da su marčanski samostan i crkva oduvijek bili sjedište grkokatoličke biskupije, a ne pravoslavne episkopije i koja se nije odnosila na ostale manastire niti na pravoslavnu Karlovačku mitropoliju kao crkvenu instituciju. ${ }^{25}$

Za razliku od autora koji su stalno isticali Habsburšku Monarhiju kao netrpeljivu katoličku državu, moramo spomenuti i autore koji su iznijeli drugačiju ocjenu habsburške vjerske politike: C. Ingrao je 1994. godine spomenuo Krajinu u Hrvatskoj kao tolerantnu sredinu za pravoslavne Srbe, a L. Orešković je analizirajući katolicizam na području Senjsko-modruške biskupije u 17. i 18. stoljeću kroz misionarsko djelovanje na preobraćenju pravoslavaca, protestanata i muslimana zaključio da se

24 Karl Kaser, Slobodan seljak i vojnik. Povojačenje agrarnog društva u Hrvatsko-slavonskoj Vojnoj krajini (1535.-1881.), sv. 2: Povojačeno društvo (1754-1881.) (Zagreb: Naprijed, 1997), 185-186; Kudelić, “Čaplovičeva povijest Marčanske biskupije”, 143-160, 170 i bilješka 2. u ovom tekstu.

25 Ovidiu Ghitta, “The first Greek Catholic catechisms in Hungary and Transylvania”, u: Confessional Identity in East-Central Europe, ur. Maria Craciun, Ovidiu Ghitta, Graeme Murdock (Farnham: Ashgate, 2002),154; Tanner, Hrvatska-država stvorena u ratu, 67, 74-75; John Fine, When Ethnicity Did not Matter in the Balkans. A Study of Identity in Pre-Nationalist Croatia, Dalmatia, and Slavonia in the Medieval and Early-Modern Periods (Ann Arbor: The University of Michigan Press, 2006), 372; Kudelić, “Čaplovičeva povijest Marčanske biskupije", 171-174. 
ciljevi Habsburgovaca i Rimske kurije nisu uvijek poklapali, a da su preobraćenja muslimana bila uspješnija za razliku od preobraćenja pravoslavaca, kojima se krajinska administracija prilagođavala. ${ }^{26} \mathrm{I} \mathrm{D}$. Roksandić spomenuo je habsburšku politiku vjerske trpeljivosti zbog strateških razloga na jugoistoku Europe na kraju 17. i početkom 18. stoljeća, koju je ocijenio i jedino mogućom politikom zbog velikoga udjela pravoslavnih vjernika Pećke patrijaršije u Vojnoj krajini, napomenuvši da su se interesi Habsburgovaca samo donekle podudarali s interesima katoličke crkvene hijerarhije glede unije te da su oni pronašli način za sporazum o vjerskim pravima pravoslavnih Vlaha. No, iznio je i dvojbenu tezu o rasprostranjenoj vjerskoj snošljivosti među običnim krajišnicima, uz brojne prelaske iz pravoslavlja u katoličanstvo i obratno i izvan domašaja crkvenih hijerarhija i krajiških vlasti jer ostaje otvorenim pitanje kako je bilo moguće mijenjati vjeroispovijest i crkvenu pripadnost bez znanja i utjecaja određene crkvene hijerarhije, kao ni koje arhivsko gradivo potvrđuje ovu tezu ako tu pojavu nisu registrirale ni crkvene hijerarhije ni krajiške vlasti. Naime, postojeće arhivsko gradivo o pitanju unije, na primjer izvješća katoličkih biskupa i osoba koje su boravile u Krajini i slale prva izvješća u Rim i Beč, pokazuje da je i na pravoslavne Vlahe i katolike utjecalo pravoslavno svećenstvo lojalno pećkim patrijarsima, čiji su egzarsi vizitirali krajiško područje držeći ga svojim jurisdikcijskim područjem, a arhivsko gradivo navodi i pritiske na katolike da prihvate pravoslavlje u sredinama gdje su bili u manjini i prijetnje pravoslavnim krajišnicima koji su bili skloni katoličanstvu, a kao jedan od najkarakterističnijih razloga za prihvaćanje pravoslavlja navodi se mogućnost razvrgavanja brakova sklopljenih u Katoličkoj crkvi jer ih je pravoslavno svećenstvo držalo nevažećima. Kako su prema ovome autoru odnosi između jedne i druge vjerske zajednice (katoličkih krajišnika i pravoslavnih Vlaha) u Krajini nerijetko bili i odnosi neravnopravnosti u društvenome smislu, a vjerski odnosi metaforično su izražavali njihove društvene različitosti jer su se Vlasi zbog povlastica i vjere osjećali različitima od većine podložničkoga stanovništva, nejasno je zašto bi pravoslavni Vlasi dobrovoljno prihvaćali katoličku vjeru ako bi time došli u isti položaj kao i katolici, to jest kada bi nestao spomenuti metaforični izraz njihove društvene različitosti, koji autor spominje. Naime, Vlasi su odbijali i prijedloge o samo simboličnom obeštećenju zagrebačkoga biskupa i vlastele na čijim su posjedima

\footnotetext{
26 Charles W. Ingrao, The Habsburg Monarchy 1618-1815 (Cambridge: Cambridge University Press, 1994), 29; Luc Orešković, “La notion de conversion aux frontières de l' Europe: un aspect du catholicisme dans le dioecèse pde Senj-Modruš aux XVIIe et XVIIIe siècles", Croatica Christiana periodica 28 (2004), br. 53: 89-116. Zanimljivo je da Petr Klapka u monografiji o životu generala Jeana Louisa Raduita de Souchesa, zapovjednika Varaždinskog generalata od 1671. do 1681. godine, kada je marčanski biskup bio Pavao Zorčić (1671. - 1685.), uopće nije spomenuo zbivanja u generalatu tijekom Souchesovog zapovijedanja nego samo velikašku urotu i njegovo sudjelovanje u dvorskom povjerenstvu koje je trebalo ispitati djelovanje urotnika i odlučiti o njihovom kažnjavanju. Opširnije: Petr Klapka, Jean Louis Ratuit de Souches (1608-1681). De La Rochelle au service des Habsburgs. Contribution à l'étude des migrations nobiliaires francophones dans les pays de la Couronne de Bohême aux XVIIe-XVIIIe siècles (Paris: Honoré Champion, 2015), 244-248.
} 
naseljeni, držeći to nametanjem podložničkoga položaja čak i kad nitko nije spominjao promjenu vjere, a u tome su ih podržavali i krajiški katolici. ${ }^{27}$

Nakon ove knjige u tekstu M. Kurelca i Z. Ladića ponovno nalazimo tezu o uhićenju marčanskoga biskupa Gabrijela Mijakića zbog sudjelovanja u Zrinsko-frankopanskoj uroti, dok je L. Steindorff istaknuo da su Simeonovim posvećenjem 1607. godine položeni temelji pravoslavnoj hijerarhiji na habsburškome teritoriju ne objasnivši kako je to bilo moguće ako habsburške vlasti to posvećenje nikad nisu službeno potvrdile nego je od 1611. godine službeno postojala samo grkokatolička/unijatska crkvena hijerarhija. Ponovio je tezu o Simeonovom prihvaćanju unije na sinodi u Marči 1611. godine time što je priznao papu kao vrhovnoga poglavara (zadržavajući pravo na upotrebu istočnoga obreda i crkveno-slavenskoga jezika), no prema arhivskome gradivu Simeon je prihvatio uniju u Rimu pred kardinalom Robertom Bellarminom na temelju odredbi Firentinskoga koncila, a o odnosima zagrebačkoga biskupa Petra Domitrovića i Simeona nije mnogo poznato. Poput većine povjesničara i Steindorff je naglasio da je unija dospjela u defanzivu kada je Bečki dvor zajamčio slobodu vjere Arseniju III. Crnojeviću. ${ }^{28}$

I rad N. Štefanec o toleranciji i netoleranciji u Hrvatsko-Slavonskom Kraljevstvu početkom 17. stoljeća sadrži zaključke koje je potrebno detaljnije kontekstualizirati jer je autorica samo navela da je 1609. godine utemeljena pravoslavna episkopija koja je trebala služiti vjerskim potrebama pravoslavnih vjernika u Ugarskoj, Hrvatskoj, Slavoniji i Žumberku ne napomenuvši da se radilo o Simeonovome imenovanju pravoslavnim episkopom zapadnih strana poznatih pod nazivom "Vretanija", koje je donio sinod Pećke patrijarije na čelu s patrijarhom Jovanom u Osmanskome Carstvu 1609. godine, dakle u drugoj državi, a da ga habsburške vlasti nikada nisu službeno imenovale pravoslavnim episkopom u Monarhiji niti su prije 1695. godine odobrile postojanje samostalne pravoslavne crkve. Simeon je pod nepoznatim okolnostima posvećen pravoslavnim episkopom 1607. godine u Raabu (Győr), nakon čega je otišao u Peć gdje je dvije godine kasnije potvrđen vretanijskim episkopom, ali je u proljeće 1611. godine prema povelji nadvojvode Ferdinanda imenovan biskupom Vlaha i Rašana pod uvjetom da će među njima iskorijeniti vjerovanja i običaje protivne Katoličkoj crkvi. Nakon toga je u Rimu pred kardinalom Robertom Bellarminom prihvatio uniju i u studenome iste godine posvećen je i potvrđen kao unijatski/grkokatolički biskup.

27 Roksandić je u knjizi objavio hrvatski prijevod brevea pape Pavla V. dodijeljenog Simeonu u Rimu u studenome 1611. godine, koji je prevela Zvjezdana Sikirić-Assouline, te izvod iz matične knjige Gradačkoga sveučilišta s podacima o podrijetlu i školovanju ivanićkog župnika Martina Dobrovića. Na temelju ovog dokumenta, koji je prevela Zrinka Blažević, razvidno je da je prezime ovog župnika, koji je sa Simeonom išao u Rim, bilo Dobrović, a ne Dubravić, koje nalazimo kod nekih autora, a da je podrijetlom bio "Vlah Bosanac". Opširnije: Roksandić, Etnos, konfesija, tolerancija, 51-53, 248-252, 257, 260; Kudelić, Marčanska biskupija, 162-163.

28 Miroslav Kurelac, Zoran Ladić, "Pokret za odcjepljenje Hrvatskog Kraljevstva od Habsburške Monarhije”, u: Povijest Hrvata. Druga knjiga. Od kraja 15. stoljeća do kraja Prvog svjetskog rata, ur. Mirko Valentić, Lovorka Čoralić (Zagreb: Školska knjiga, 2005), 109; Ludwig Steindorff, Povijest Hrvatske: od srednjeg vijeka do danas (Zagreb: Naklada Jesenski i Turk; Institut društvenih znanosti Ivo Pilar, 2006), 78-79; Kudelić, Marčanska biskupija, 145-149, 184-185, 188-189. 
Jurisdikcijsko područje spomenuto u papinskom breveu 1611. godine određeno mu je kao unijatskom/grkokatoličkom biskupu sa sjedištem u samostanu S. Mihaela Arkanđela u Marči a ne pravoslavnome episkopu, a ono je otprilike odgovaralo području koje je pojmom "Vratanija" nazivala crkvena hijerarhija Pećke patrijaršije. Treba napomenuti da u papinskom breveu izdanome Simeonu 1611. godine nije bilo govora o podređenosti zagrebačkome biskupu, a ni habsburške vlasti u Beču nisu uvjetovale imenovanje marčanskih biskupa sve do Gabrijela Mijakića njihovim prihvaćanjem položaja vikara za kršćane grčkoga obreda u Zagrebačkoj biskupiji. Autorica je spomenula i pravoslavnu hijerarhiju u Slavoniji, koja se hijerarhijski morala podvrgnuti zagrebačkim biskupima, misleći vjerojatno na marčanske biskupe koji su naslijedili Simeona na biskupskoj stolici, no oni su u Beču imenovani biskupima unijatske/grkokatoličke Svidničke/Vretanijske (Marčanske biskupije), a ne pravoslavnim episkopima i kao takvi su, barem formalno, pripadali katoličkoj hijerarhiji pa zaključak da su zagrebački biskupi htjeli ukinuti pravoslavnu episkopiju ne odgovara činjenicama jer su marčanski (“vlaški”) biskupi na Bečkom dvoru smatrani biskupima unijatske/grkokatoličke biskupije, a Beč u to vrijeme na području Hrvatske i Ugarske nije prihvaćao postojanje ikakve pravoslavne crkvene hijerarhije. Zagrebački biskupi Benedikt Vinković (1637. - 1642.) i Petar Petretić (1648. - 1667.) spomenute su biskupe zbog njihova ponašanja smatrali prividnim unijatima koji su formalno pred habsburškim vlastima prihvaćali uniju, ali u stvarnosti su i dalje priznavali autoritet pećkoga patrijarha i ponašali se kao pravoslavni episkopi koji nisu radili u korist unije pa su bezuspješno tražili njihovo smjenjivanje i imenovanje potvrđenoga unijata/ grkokatolika. Iako su oba zagrebačka biskupa i spominjala ukidanje "vlaške" biskupije zbog, po njihovome mišljenju, prijetvornoga ponašanja biskupa koji su slijedili nakon Simeona, bili su svjesni da Beč to neće prihvatiti pa su predlagali smjenjivanje onih biskupa koje su držali samo prividnim grkokatolicima i postavljanje grkokatoličkoga biskupa kojega bi imenovao vladar, a nikako samostalno birali krajišnici, što je do tada bio običaj koji su vojne vlasti tolerirale, i koji je morao biti podređen zagrebačkome biskupu kao njegov vikar za kršćane grčkoga obreda. Benedikt Vinković je kao takvu osobu predlagao Rafaela Levakovića, dok je Petar Petretić u najopsežnijemu izvješću 1662. godine o "vlaškoj bikupiji” analizirao tri kandidata koji su željeli biskupski naslov nakon smrti Save Stanislavića i nije podržavao Gabrijela Mijakića, kojega je Bečki dvor ipak na kraju imenovao. Primijetivši da su Habsburgovci i Katolička crkva imali različite vojne i ekonomske interese i da religija nije bila primarni problem u pregovorima Katoličke crkve s pravoslavnim Vlasima, autorica je ustvrdila da vjerska netolerancija na krajiškome području nije bila izražena u onako nasilnim oblicima kao u susjednim habsburškim zemljama jer su Hrvatski sabor i Habsburgovci bili zaokupljeni pravnim, ekonomskim i vojnim položajem doseljenih pravoslavnih Vlaha, a ne njihovom vjeroispoviješću. Međutim, otvorenom ostaje teza da je unija umanjila mogućnost vjerskih sukoba i omogućila Habsburgovcima dovođenje većih skupina Vlaha jer pretpostavlja postojanje vjerskih sukoba u Krajini u tome razdoblju, o čijoj se pojavi, intenzitetu i trajanju zapravo ne zna mnogo. Iako je autorica zaključila da se pravoslavni manastir Gomirje razvio kao pravoslavno središte 
zbog slabosti Katoličke crkve u Hrvatskoj krajini i naseljavanja Vlaha na plemićke, a ne crkvene posjede, potrebno je napomenuti da unija nije zaživjela onako kako su to očekivali zagrebački biskupi ni na području Varaždinskoga generalata i to zbog nesklonosti vojnih vlasti da udovolje zahtjevima biskupa Benedikta Vinkovića i Petra Petretića, što pokazuju onovremena izvješća. Djelovanje Katoličke crkve u oba generalata u prvome je redu ovisilo o procjeni krajiških vojnih vlasti o posljedicama unije za unutrašnje stanje u krajinama, pa je i u slučaju Gomirja slobodno ispovijedanje pravoslavne vjere bilo rezultat politike održavanja stabilnosti Vojne krajine bez obzira na reakcije Katoličke crkve, čije zahtjeve ni u Varaždinskome generalatu Bečki dvor nije bio spreman ispuniti, što pokazuju imenovanja pet marčanskih /"vlaških"/ biskupa u Beču između 1630. i 1663. godine koje Rim nije prihvatio ni potvrdio niti su o njihovome imenovanju konzultirani zagrebački biskupi. ${ }^{29}$

Samo općenite zaključke o uniji sadrži i rad W. Bracewell o historiografiji Tromeđe (Triplexa Confiniuma), u kojemu je autorica ustvrdila da su na mletačkim i habsburškim granicama postojali jaki pritisci za uniju s Katoličkom crkvom i da je postojala podrška onim pravoslavnim crkvenim dužnosnicima koji su priznali autoritet Rima. Međutim, iako je istaknula da je unija izgubila mnogo od svojih dobitaka zbog velike migracije u habsburške zemlje i privilegija dodijeljenih Arseniju III. Crnojeviću, nije navela tko je konkretno pritiskao pravoslavne doseljenike niti koje je to uspjehe unija imala. Iako je napomenula da su novija istraživanja utvrdila nekoliko razloga ograničenoga uspjeha unije, prvenstveno utjecaj pećkih patrijarha na krajišnike i način provođenja unije koji su zagovarali zagrebački biskupi, izostalo je objašnjenje zašto je unija doživjela neuspjeh ako je prethodno zaključeno da su habsburške i mletačke vlasti podržavale pravoslavne episkope koji su bili skloni uniji. Naime, ova teza sugerira da je otpor protivnika unije bio toliko snažan da ga ni habsburške ni mletačke vlasti nisu mogle riješiti, što je teško povjerovati podsjetimo li se da su te iste vlasti vrlo učinkovito onemogućile širenje protestantizma na svojemu teritoriju. ${ }^{30}$ I mađarski povjesničar A. Forgó ukratko je spomenuo marčanski samostan u knjizi o pokušajima unije ne samo pravoslavnih kršćana s Katoličkom crkvom u zemljama Krune sv. Stjepana, nego i unije protestantskih crkava, o čemu šira javnost zna vrlo malo, ali nije naveo ime biskupije. Koristeći Nillesove podatke i stariju literaturu iznio je i neke netočne podatke, na primjer naveo je da su brojne srpske izbjeglice nakon Kosovske bitke (!) stigle u Hrvatsku i južnu Ugarsku gdje su nazivani uskocima te netočno naveo zaključio da je Simeon Vratanja već od 1607. godine počeo pregovore s

29 Potrebno je napomenuti da je Rim dosta kasnio u donošenju konačnih rješenja o novim biskupima, pa su odluke glede Gabrijela i Vasilija (Bazilija) Predojevića službeno donijete nakon njihove smrti, 1644. godine za Gabrijela, a 1649. godine za Vasilija. Opširnije: Nataša Štefanec, "Tolerance and Intolerance in the Croatian-Slavonian Kingdom at the Turn of the 17th Century. Contest for Gomirje", u: Tolerance and Intolerance on the Triplex Confinium. Approching the "Other" on the Borderlands Esatern Adriatic and beyond 1500-1800, ur. Egidio Ivetić, Drago Roksandić (Padova: Cleup, 2007), 145-147, 183; Uhać, Marčanska biskupija, 24; Kudelić, Marčanska biskupija, 265-268.

30 Wendy Bracewell, "The Historiography of the Triplex Confinium: Conflict and Community on a Triple Frontier, 16th-18th centuries", u: Frontiers and the Writing of History, 1500-1850, ur. Stevan G. Ellis, Raingard Eßer (Hannover: Wehrhahn, 2006), 220-221. 
kardinalom Robertom Bellarminom o uniji jer je te godine Simeona za pravoslavnoga episkopa posvetio nepoznati korintski arhiepiskop Kozma, a o Simeonovu životu do odlaska u Rim s župnikom Martinom Dobrovićem 1611. godine ne znamo ništa osim da je 1609. godine u Peći posvećen za pravoslavnoga vratanijskog episkopa. Forgó je napomenuo da je prema pravoslavnoj tradiciji Marča bila duhovno sjedište u kojemu je stolovao pravoslavni episkop, ali i pogrešno naveo da je Simeon umro 1632. godine umjesto 1634. godine, a netočno je naveo i da je unijatski kaluđer Metodije Telecki, kojega je Kongregacija za širenje vjere uputila među krajišnike 1628. i 1629. godine, uživao podršku biskupa Pavla Zorčića (biskup 1671. - 1685., op. Z.K.) jer je tada marčanski biskup još bio Simeon Vratanja (umro 1634.), koji se susreo s Terleckim. Forgó nije govorio o Marčanskoj biskupiji tijekom 18. stoljeća nego je samo spomenuo da je 1777. godine nastala grkokatolička biskupija u Križevcima za unijatske Srbe i zaključio da je omogućavanjem djelovanja Srpske pravoslavne crkve došlo do stapanja "unijatske srpske crkve" s pravoslavljem. ${ }^{31}$

O Marčanskoj biskupiji i pojavi grkokatoličanstva na području Hrvatsko-slavonske vojne krajine pisao je i Ž. Holjevac, prema kojemu je dio doseljenih kršćana istočnog obreda pod vodstvom vladike Simeona priznao zagrebačkog biskupa Petra Domitrovića svojim poglavarom i time ujedno i prihvatio jedinstvo s Katoličkom crkvom, no treba istaknuti da ne postoje podatci o Simeonovom priznavanju zagrebačkoga biskupa kao posebnome činu kojim bi on prihvatio uniju nego je Simeona prvo u proljeće 1611. godine biskupom potvrdio nadvojvoda Ferdinand pod uvjetom da ukloni običaje suprotne katoličkoj vjeri, a uniju je formalno prihvatio u studenome iste godine u Rimu ispovjedivši prije toga katoličku vjeru pred kardinalom Robertom Bellarminom na temelju odredbi Firentinskoga sabora. Holjevac je upozorio i na mišljenje da se u Marči u proljeće 1611. radilo samo o raspravi o pitanju davanja desetine zagrebačkome biskupu, odnosno da je to bilo svojevrsno socio-ekonomsko pozicioniranje Simeonovih sljedbenika bez nekih osobitih implikacija vjerske naravi, ali je napomenuo da su se i kroz eklezijalnu dimenziju prelamala sva otvorena pitanja u odnosu vjernika istočnoga obreda prema novome okruženju u kojemu su se nalazili. Zaključivši da su marčanski biskupi usprkos određenoj habsburškoj novčanoj potpori bili prilično sputani u širenju unije jer Bečki dvor nije bio sklon nasilnome unijaćenju te su sami unijati s vremena na vrijeme bili više tolerirani nego što ih se promoviralo, istaknuo je da je neuspjeh unije bio posljedica istodobnoga podupiranja sjedinjenih (grkokatolika) i toleriranje nesjedinjenih (pravoslavaca) i protivljenja sve utjecajnije pravoslavne crkvene hijerarhije uniji. I ovaj je autor prihvatio tezu da je biskup Gabrijel Mijakić smijenjen i zatvoren zbog optužbe za sporazumijevanjem s urotnicima, no njegov zaključak da je Mijakićev nasljednik Pavao Zorčić bio skloniji približavanju Katoličkoj crkvi potrebno je ispraviti jer je Zorčić bio školovan u katoličkim ustanovama i posvećen u Rimu 1671. godine kao sjedinjeni/unijatski biskup i kao takav pripadao Katoličkoj crkvi i bio njezin legitimni predstavnik, od kojeg se očekivalo

31 András Forgó, Kirchliche Einigungsversuche in Ungarn. Die Unionsverhandlungen Christophorus Rojas Y Spinolas in der zweiten Hälfte des 17. Jahrhunderts (Mainz: Verlag Phillip von Zabern, 2007), 56-58, 84-85, 121; Jačov, Spisi Kongregacije za propagandu vere, 132-141. 
širenje unije među krajiškim pravoslavcima. Teza da je položaj onih koji su prihvatili uniju unutar Katoličke crkve bio neodređen, i da se isprva nije ni pomišljalo da bi grkokatolici u katoličkome okrilju mogli trajnije zadržati određene posebnosti je diskutabilna jer su grkokatolici/unijati pripadnici Katoličke crkve kao katolici istočnoga obreda, a očuvanje njihovih posebnosti, to jest obreda i običaja, prilagođenih nauku Katoličke crkve, zagovarali su mnogi biskupi i službene crkvene vlasti, dok su se neki biskupi tome protivili. Kao primjer mogu se spomenuti različiti stavovi o uniji kod smederevskoga biskupa Alberta Renđića, koji je zagovarao bezuvjetno prihvaćanje latinskog obreda, i Metodija Terleckoga, ukrajinskoga grkokatoličkog kaluđera, koji je vizitirao Krajinu 1629. godine i zagovarao postupno provođenje unije uz uvažavanje nekih posebnosti istočnoga obreda. S druge strane, Kurija je 1624. godine unijatskim Rusinima u Kijevskoj metropoliji zabranila prijelaz s grčkoga na latinski obred. Potpuno prihvaćanje latinskoga obreda povremeno su predlagali pojedini rimokatolički biskupi, ali ti prijedlozi ovisili su prvenstveno o mišljenju državnih vlasti u mletačkoj Dalmaciji i habsburškoj Vojnoj krajini, čiji se stavovi o uniji pravoslavnih kršćana nisu nužno podudarali s očekivanjima Rimske kurije, pa najčešće nisu bili ni prihvaćeni. Svu kompleksnost odnosa rimokatoličkih biskupa prema pravoslavnim kršćanima, koji su se nalazili u njihovim biskupijama najbolje oslikavaju prijedlozi zagrebačkih biskupa Benedikta Vinkovića i Petra Petretića, koji su bili skloni podržati postupno nametanje latinskog obreda, ali su iz pragmatičnih razloga zagovarali postavljanje unijatskog biskupa koji bi bio njihov vikar i bio odgovoran za postupno odgajanje grkokatoličkoga podmlatka koji bi zamijenio svećenstvo za koje su tvrdili da je samo prividno prihvatilo uniju ili joj se otvoreno protivilo, no na Dvoru su doživjeli predbacivanja da ih pokreću materijalni interesi, to jest želja za povratom imanja koje je pripadalo marčanskoj crkvi i samostanu..$^{32}$ Problem crkvene unije i Marčanske biskupije djelomično je spominjao i $\mathrm{H}$. Petrić u različitim radovima i monografiji o Varaždinskome generalatu. Analizirajući pojavu tolerancije i netolerancije na širemu području mletačkih, habsburških i osmanskih krajina na primjeru grada Koprivnice spomenuo je i postojanje pravoslavnih stanovnika u Koprivnici, a proces njihova nestajanja stavio je u povijesni kontekst zbivanja od 1630. godine, kada su objavljeni vlaški statuti, imenovan novi marčanski biskup Maksim Predojević, koji nije bio sklon Katoličkoj crkvi i uniji, a koprivničkim župnikom postao je Matija Sumer, kojemu je Petrić pripisao ključnu ulogu u protjerivanju protestanata iz Koprivnice. Na temelju ovih činjenica zaključio je da je nestanak Vlaha u Koprivnici povezan sa Sumerovim djelovanjem na vjerskim preobraćenjima ne samo protestanata nego i pravoslavnih Vlaha, što je po njegovom mišljenju bilo moguće zato što "Statuta Valachorum"nisu obuhvaćala gradska naselja nego samo sela u Varaždinskome generalatu pa su Vlasi izvan generalata ostali bez zaštite, što je ubrzalo njihovu konverziju. Petrić je istaknuo da je učvršćenje vojnokrajiškoga ustroja bilo povezano s

32 Željko Holjevac, Nenad Moačanin, Hrvatsko-slavonska Vojna krajina i Hrvati pod osmanskom vlašću (Zagreb: Leykam International, 2007), 69, 87-92; Kudelić, Marčanska biskupija, 179-182; Tadhg Ó hAnnracháin, Catholic Europe, 1592-1648. Centre and Peripheries (Oxford: Oxford University Press, 2015), 89. 
katoličkom obnovom i stvaranjem, to jest obnovom katoličke infrastrukture i da su na području Vojne krajine u najvećem broju slučajeva obnavljane prijašnje župe te je iznio diskutabilnu tezu da su podaci iz izvješća zagrebačkih biskupa o buntovnome ponašanju Vlaha i njihova svećenstva i pritisku pravoslavnih Vlaha na katolike bila pretjerivanja. Istaknuvši da je dio vlaškoga pravoslavnog stanovništva u procesu katoličke obnove prihvatio katoličanstvo naveo je da počeci manastira Lepavine počivaju na crkvenoj predaji i da prvi točni podaci potječu iz 17. stoljeća, a na temelju Kašićevih i Moačaninovih radova iznio je podatke o prvim pravoslavnim episkopima na krajiškome području napomenuvši da crkvena predaja govori o počecima Marče još za vrijeme vladavine kralja Maksimilijana I. (1564. - 1576). No, teza o katoličkoj obnovi u Krajini otvara pitanje kako je ona mogla biti privlačno područje pravoslavnim kršćanima za naseljavanje ako su bili izloženi pritisku katoličke hijerarhije, odnosno kako je bilo moguće istovremeno provoditi katoličku obnovu i izgrađivati stabilni krajiški sustav uz pretpostavljenu izloženost pravoslavnih doseljenika pritiscima bilo koje vrste s obzirom na upletenost Monarhije u ratove tijekom prve polovice 17. stoljeća, na primjer Tridesetogodišnji rat, za koje su bili potrebni krajišnici. Općenite zaključke o katoličkoj obnovi tek bi trebalo potkrijepiti konkretnijim podacima o eventualnim prijelazima pravoslavnih krajišnika na katoličanstvo i obnavljanju župa na krajiškome području iz arhivskoga gradiva koje eventualno opisuje taj proces, bilo onoga koje su ostavili krajiški zapovjednici, bilo gradiva zagrebačkih biskupa, koji bi određeni napredak katoličke obnove svakako isticali u izvješćima upućenima Rimu ili Beču. Iscrpniji odgovor na ovo pitanje tek se iščekuje zato što u izvješćima zagrebačkih biskupa iz prve polovice i sredine 17. stoljeća nalazimo podatke koji ne idu u prilog tezi o katoličkoj obnovi u Krajini. Zagrebački biskup Benedikt Vinković napomenuo je da krajiško područje nije bilo vizitirano šezdeset godina prije njega, da od Vlaha nije ništa dobivao s posjeda Zagrebačke biskupije koje su zaposjeli te da su krajiški zapovjednici štitili Vlahe i protivili se njihovom odvajanju od Slavonaca i Predavaca te da nisu podržavali uniju. Nakon njega Petar Petretić upozoravao je na stalnu prisutnost egzarha pećkih patrijarha na krajiškome području, koji su provjeravali ponašanje pravoslavnih Vlaha i pobirali porez među njima te ukazivao na učestalo nekontrolirano prelaženje pravoslavnih kaluđera iz Krajine u Osmansko Carstvo i obratno te na prijelaze katolika na pravoslavlje, na što krajiške vojne vlasti uopće nisu reagirale, a što bi se očekivalo u slučaju striktnog provođenja katoličke obnove. ${ }^{33}$ Najopsežniju studiju o Marčanskoj biskupiji objavio je Z. Kudelić, a ona obuhva-

33 Petrić je pretpostavio i da bi Predavci, koje izvješća zagrebačkih biskupa između 1641. i 1662. godine spominju kao Bosance i katolike doseljene u Krajinu iz Bosanskog pašaluka, mogli biti pravoslavni Vlasi koji su na posjedima zagrebačkih biskupa krajem 16. i početkom 17. stoljeća prešli na katoličanstvo zato što izvješća ne govore o njihovoj vjerskoj pripadnosti u ranijim razdobljima, ali kako je sam napomenuo da za ovu tezu nema dokaza u izvorima tek bi sustavnije istraživanje odgovarajućeg arhivskog gradiva moglo pokazati njezinu utemeljenost. Opširnije: Hrvoje Petrić, "Katolička obnova i konfesionalne tolerancije / netolerancje na širem prostoru Triplexa Confiniuma do oko 1630. godine: primjer grada Koprivnice", Croatica Christiana periodica 30 (2006), br. 57: 55-63; Hrvoje Petrić, "Roman Catholic Church and Confesional Revival. (In)tolerance in a Complex Borderland up to 1630s. Case study of the Town of Koprivnica", u: Tolerance and Intolerance on the Triplex Confinium. Approching the "Other" on the Borderlands: Esatern Adriatic and beyond 1500-1800, ur. Egidio Ivetić, Drago 
ća razdoblje od posvećenja biskupa Simeona Vratanje u Rimu 1611. godine do napuštanja marčanskoga samostana 1755. godine i utemeljenja grkokatoličke Križevačke biskupije 1777. godine. Prema mišljenju ovoga autora razumijevanje događaja koji su doveli do utemeljenja i nestajanja Marčanske biskupije i utemeljenja nove grkokatoličke biskupije u Križevcima bilo je moguće ne samo analizom habsburške vjerske i crkvene politike tijekom 17. i 18. stoljeća nego i propitivanjem teze starije historiografije o stalnome katoličkom pritisku na pravoslavne krajišnike Vojne krajine. Za razliku od drugih autora zaključio je da izvor koji mnogi autori spominju kao dokaz o masovnom prihvaćanju unije u proljeće 1611. godine prije govori o raspravi glede plaćanja crkvene desetine zagrebačkom biskupu nego o uniji, a upozorio je na neodrživost teze o početku unije s navodnim pravoslavnim podrijetlom zagrebačkoga biskupa Petra Domitrovića nakon otkrića da je Domitrović bio rodom iz Hrvatskog zagorja. Dok je većina autora neuspjeh unije povezivala s dolaskom pećkog patrijarha Arsenija III. Crnojevića u Monarhiju, ovaj je autor istaknuo da unija nije zaživjela od samih početaka Marčanske biskupije jer se Bečki dvor njome morao baviti istovremeno kad i vlaškim pitanjem i to u vrlo nepovoljnim vanjskopolitičkim okolnostima, usred Tridesetogodišnjega rata. Prema njegovom mišljenju preporuka Bečkoga dvora iz 1627. godine da Vlasi sami među kaluđerima odabiru biskupa sklonoga Katoličkoj crkvi te odbacivanje zahtjeva za vizitiranjem Krajine, protjerivanjem pravoslavnog svećenstva i kaluđera i otvaranjem škola za Vlahe jasno su pokazali kako Dvor na krajiškome području nije namjeravao voditi crkvenu politiku kakvu su očekivali katolički biskupi koji su zagovarali uniju, pa su djelomične promjene nastupile tek nakon 1670. godine i smjenjivanja biskupa Gabrijela Mijakića. Za razliku od drugih autora Kudelić je napomenuo da je Mijakić (prema arhivskome gradivu) smijenjen zato što je Bečki dvor procijenio da se nije ponašao kao grkokatolički/unijatski biskup i nije ispunio obveze pod kojima je dobio biskupiju, a da je krajišnicima njegovo smjenjivanje objašnjeno kao posljedica sudjelovanja u uroti kako bi bili izbjegnuti veći krajiški neredi, iako konkretniji dokazi o njegovoj ulozi u uroti nikada nisu izneseni. Govoreći o povijesti Marčanske biskupije od početka 18. stoljeća napomenuo je da su marčanski biskupi nakon učvršćenja pravoslavne crkvene hijerarhije 1695. godine stvarnu jurisdikcijsku vlast obnašali samo na području Varaždinskoga generalata iako je Bečki dvor nekima od njih jurisdikciju proširio i na Hrvatsku i Slavoniju. Vladavinu Karla VI. istaknuo je kao razdoblje u kojemu su Vlasi iz Varaždinskoga generalata otvoreno odbili prihvatiti marčanske grkokatoličke biskupe kao legitimne biskupe i zahtijevali da i u tome generalatu bude postavljen pravoslavni episkop, čemu je Bečki dvor udovoljio utemeljivši Lepavinsko-severinsku episkopiju 1734. godine sa sjedištem u Severinu, iako su Vlasi tražili da marčanski samostan postane sjedište

Roksandić (Padova: Cleup, 2007), 253-261; Hrvoje Petrić, Pogranična društva i okoliš: Varaždinski generalat i Križevačka županija u 17. stoljeću (Samobor; Zagreb: Meridijani; Društvo za hrvatsku ekonomsku povijest i ekohistoriju, 2012), 144-146, 171, 175, 182-185, 195, 227-231, 338; Kudelić, Marčanska biskupija, 234-271; Josip Adamček, Bune i otpori: seljačke bune u Hrvatskoj u XVII stoljeću (Zagreb: Globus, 1986), 292-297; Holjevac, Moačanin, Hrvatsko-slavonska Vojna krajina, 88; Roksandić, Etnos, konfesija, tolerancija, 248-252, 257, 260. 
pravoslavne episkopije. Sažimajući razloge koji su doveli do nestanka Marčanske biskupije i neuspjeha unije Kudelić je - uz već spomenuto različito poimanje obreda i vjere te nepostojanje političke volje na Bečkom dvoru da odlučnije provede uniju upozorio i na poistovjećivanje unije s gubitkom povlaštenoga krajiškog statusa i pokmećivanjem, izazvano zahtjevima zagrebačkih biskupa da bi im Vlasi s crkvenih posjeda koji su ušli u sastav Krajine trebali davati određeno, pa makar i simbolično obeštećenje. Međutim, nije držao opravdanim prozivati zagrebačke biskupe da su inzistiranjem da im marčanski biskupi budu vikari za kršćane grčkoga obreda pridonijeli neuspjehu unije jer su se oni samo pozivali na onovremene važeće odredbe o načinu sjedinjenje kršćana istočnog obreda u Katoličkoj crkvi. Bečki dvor te odredbe nije uvažavao nego je odluke o religijskoj politici u Krajini donosio na temelju procjena o njezinoj svrsishodnosti, odnosno njezinome mogućem utjecaju na stabilnost Vojne krajine, donesenima pod utjecajem mišljenja krajiških vojnih zapovjednika, koji su se tijekom 17. stoljeća zbog česte upletenosti Monarhije u europske sukobe širih razmjera protivili i zamisli o crkvenoj uniji i svim drugim postupcima koji su mogli izazvati krajiške nemire. Isti je autor u nekoliko opsežnijih radova analizirao pojedina razdoblja povijesti Marčanske biskupije i odgovarajuće arhivsko gradivo, a u članku o utjecaju knjige Slovaka J. Čaploviča o Slavoniji i Hrvatskoj iz 1819. godine na krajišku historiografiju detaljno je prikazao različite interpretacije krajiške historiografije o ovom pitanju i ukazao na utjecaj historiografije iz 19. stoljeća na inozemne autore u 20. stoljeću. ${ }^{34}$ Zanimljivu kompilaciju o ovoj temi povodom proslave 400 . obljetnice unije objavila je N. Kauzlarić, koja je na temelju dosad objavljene opsežne literature opisala povijest ove biskupije, istražila podatke o Marči u predturskome vremenu, te ukazala na potrebu arheoloških istraživanja na lokalitetu gdje se nalazio samostan u Marči, u kojoj su pronađeni raznovrsni predmeti, prvenstveno pećnjaci. Ujedno je iznijela i manje poznate podatke o povijesti marčanskoga kraja tijekom 19.

34 Kudelić, Marčanska biskupija, 49, 56., 133., bilj. 196, 497-506. Kritički osvrti: Irena Smiljanić, "Zlatko Kudelić, Marčanska biskupija. Habsburgovci, pravoslavlje i crkvena unija u Hrvatsko-slavonskoj vojnoj krajini (1611.-1755.), Zagreb: Hrvatski institut za povijest, 2007., 585 str.”, u: Ljetopis Srpskog kulturnog društva "Prosvjeta” 13 (2008): 462-476; Dragan Vukšić, Žumberački uskoci. Unijaćenje i odnarođivanje (Zagreb: Srpsko narodno vijeće, 2015), 253-261. Osim ove monografije ovaj autor je o toj temi objavio i slijedeće radove: Zlatko Kudelić, "Rafael Levaković kao kandidat za biskupa grkokatoličke Marčanske biskupije”, u: Hereditas rerum croaticarum ad honorem Mirko Valentić, ur. Alexander Buczynski, Milan Kruhek, Stjepan Matković (Zagreb: Hrvatski institut za povijest, 2003), 113-124; Zlatko Kudelić, "Prijedlog dvorskih savjetnika caru Leopoldu I. o smjenjivanju marčanskog biskupa Gabrijela Mijakića i sužavanju vlaških povlastica iz 1668. godine”, Croatica Christiana periodica 27 (2003), br. 51: 79-100; Zlatko Kudelić, "Povijest grkokatoličke Marčanske biskupije ('biskupije Vlaha') zagrebačkog biskupa Petra Petretića iz 1662. godine”, Povijesni prilozi 22 (2003), br. 25: 187-216; Zlatko Kudelić, "Izvješće zagrebačkog biskupa Petra Petretića o Svidničkoj (Marčanskoj) biskupiji caru Leopoldu I. iz 1667. godine”, Povijesni prilozi 23 (2004), br. 26: 69-97; Kudelić, “Čaplovičeva povijest Marčanske biskupije”, 160-174; Zlatko Kudelić, "Izvješće križevačkog pukovnika Johanna Josepha Herbersteina o Svidničkoj (Marčanskoj) biskupiji iz 1666. godine”, u: Ascendere historiam. Zbornik u čast Milana Kruhek, ur. Marija Karbić, Hrvoje Kekez, Ana Novak, Zorislav Horvat (Zagreb: Hrvatski institut za povijest, 2014), 229-247; Zlatko Kudelić, "Konfesionalizacija i crkvena unija u Hrvatsko-Slavonskom Kraljevstvu na primjeru Vojne Krajine”, u: Tridentska baština. Katolička obnova i konfesionalizacija u hrvatskim zemljama. Zbornik radova, ur. Zrinka Blažević, Lahorka Plejić Poje (Zagreb: Matica hrvatska; Katolički bogoslovni fakultet u Zagrebu; Filozofski fakultet Družbe Isusove u Zagreb, 2016), 99-119. 
i 20. stoljeća te ukazala na dvojbene podatke o sudbini kapelice podignute u Marči 1925. godine u tiskovinama srpske manjine u Hrvatskoj, a u knjizi je objavljen i djelomični hrvatski prijevod darovnice zagrebačkoga biskupa Petra Domitrovića biskupu Simeonu iz 1618. godine. ${ }^{35}$ Spomenuti valja i dva djela kompilacijskoga karaktera autora G. Ivaniševića, koji je povodom obilježavanja 400. obljetnice unije u Marči 2012. godine objavio djelo pod naslovom Marčanska unija 1611. Ljetopis i pojmovnik, a 2018. godine povodom obilježavanja obljetnice osnivanja Križevačke eparhije njegovo prošireno izdanje pod naslovom Marčanska unija 1611. i Križevačka eparhija 1777. Ljetopis i pojmovnik. ${ }^{36}$

O djelovanju Rafaela Levakovića na širenje unije pisao je i R. Barišić, osvrnuvši se na temelju postojeće literature na njegov boravak u Vlaškoj i na njegov položaj i djelovanje u sklopu plana zagrebačkoga biskupa Benedikta Vinkovića da ga postavi za vikara za kršćane grčkoga obreda u Zagrebačkoj biskupiji i novoga marčanskog biskupa. Barišić je napomenuo da iz onovremene perspektive pojam unijaćenja nije imao negativnu perspektivu i da se pri njegovome provođenju nisu birala sredstva, a da se u tome vremenu pokušaji unije nisu vodili na današnji ekumenistički način, koji više smjera k razumijevanju između različitih kršćanskih crkava nego li njihovom ujedinjavanju pod svaku cijenu. Napomenuo je da je neobrazovanost pravoslavnoga svećenstva trebala poslužiti za širenje unije preko tiskanja crkvenih knjiga na ćirilici, a kao prepreke uniji, koje je uočio Levaković, spomenuo je tvrdoglavost pravoslavnog klera zbog neobrazovanosti i straha pred novinama, pristup katoličkih svećenika koji su htjeli uniju provesti brzo i tako da pravoslavci prihvate rimokatoličanstvo, za što je kao primjer naveo Jurja Rattkaya i Benedikta Vinkovića, zatim vezanost Vlaha uz vlastiti obred i tradiciju te prelaženje kaluđera s jedne strane na drugu granice, koji su održavali vjernost Vlaha pravoslavlju, kao i interese Bečkog dvora koji se nije vodio vjerskim razlozima u vjerskoj politici. Levakovićevo djelovanje Barišić je ocijenio nekonzistentnim jer iako je planirao unijaćenje provesti tiskanjem knjiga, nije se pozabavio širenjem tih knjiga među pravoslavcima, a analizirajući njegova pisma zaključio je da su imala veliku dozu samo promocije i da su trebala poslužiti kao opravdanje i objašnjenje Vinkovićevih molbi. ${ }^{37}$

\footnotetext{
35 Kauzlarić, Tragom marčanske povijesti, 19-36, 125-128, 144-148, 155-166.

36 Goran Ivanišević, Marčanska unija 1611. Ljetopis i pojmovnik (Zagreb: vlastita naklada, 2012); Goran Ivanišević, Marčanska unija 1611. i Križevačka eparhija 1777. Ljetopis i pojmovnik (Zagreb: vlastita naklada, 2018). Prvo izdanje ljetopisa i pojmovnika sadržavalo je kronološki opis zbivanja posvećenih povijesti Marčanske biskupije i Križevačke eparhije do 1985. godine, abecedni popis osoba i pojmova povezanih s poviješću Marčanske biskupije i Križevačke eparhije te hrvatske prijevode isprave kardinala Roberta Bellarmina o prihvaćanju unije Simeona Vratanje u Rimu, breve pape Pavla V. o Simeonovom imenovanju unijatskim biskupom, pismo pape Pavla VI. carici Mariji Tereziji kojim ju obavještava o utemeljenju Velikovaradinske i Križevačke grkokatoličke biskupije i pismo istog pape ostrogonskom, a dodao je i dijelove memoranduma Konstantina Stanića o Križevačkoj eparhiji i uniji iz Nillesovog djela i reskript Marije Terezije iz 1775. godine na hrvatskom jeziku o pretvaranju Svidničkog vikarijata u Križevačku dijecezu.

37 Rudolf Barišić, "Rafael Levaković i crkvena unija”, u: Zbornik o Rafaelu Levakoviću. Zbornik radova sa znanstvenog skupa "Fra Rafael Levaković", Šibenik-Skradin-Visovac 14. - 16. svibnja 2009., ur. Pavao Knezović (Zagreb, Hrvatski studiji Sveučilišta u Zagrebu, 2010), 47-82.
} 
Posljednji rad koji treba spomenuti u ovom pregledu jest rad madžarskoga povjesničara A. Molnára o Srpskoj pravoslavnoj crkvi i pokušajima unije s Rimom u 17. stoljeću. Prema njemu su pravoslavni doseljenici različitoga etničkog porijekla, koji su iz pravnih razloga nazivani Vlasima, od 1587. godine počeli dolaziti na pogranična područja Hrvatske i Slavonije, bili podređeni vojnim zapovjednicima te pripadali pod jurisdikciju pećkoga patrijarha, a problem unije povezao je sa zahtjevima plemstva i zagrebačkih biskupa za restitucijom njihovih posjeda koji su postali dio Vojne krajine. Glede događaja iz 1611. godine zaključio je da ni jedna strana nije postigla što je htjela jer su Srbi (a ne Vlasi, kako je na početku teksta nazvao pravoslavne doseljenike različitoga etničkog porijekla) gledali na uniju kao sredstvo za osiguranje svoje Crkve i olakšavanje njihove integracije, što za njih nije značilo prekid tradicionalnih i kulturnih veza jer su njihovi biskupi odlazili na posvećenje u Peć, a kaluđeri održavali veze s manastirima u Srbiji i Srijemu. Na uniju su gledali kao na izvanjski čin, neku vrstu političkoga kompromisa, a nikako promjenu religijskoga identiteta ili veza pa su ih katolički predstavnici smatrali šizmaticima. Molnár je zaključio da su katolički biskupi prvenstveno nastojali osigurati njihovu jurisdikcijsku vlast, koja je uključivala i asimilaciju u crkvenu organizaciju i latinizaciju kroz neko dulje vremensko razdoblje pa ni zagrebački biskupi nisu mogli prihvatiti stvaranje neovisne unijatske biskupije na području njihove, ionako već devastirane, biskupije. Primijetio je da su prijepor oko prava imenovanja unijatskog biskupa pod točno određenim naslovom između Rima i Beča i masovno doseljavanje Srba s njihovim patrijarhom zaustavili stvaranje novih unijatskih zajednica, što se dogodilo i u Srijemu, gdje se unijatski biskupi (zbog nedostatka podrške državnih i crkvenih vlasti) nisu mogli suprotstaviti dobro organiziranoj pravoslavnoj crkvenoj hijerarhiji i djelovanju Arsenija III. Crnojevića. Otvorenim ostaje pitanje koliko je prijepor oko naslova između Rima i Beča predstavljao stvarnu prepreku za unijom s obzirom da su krajiški zapovjednici bili posljednja instanca na koju se oslanjao Bečki dvor kod donošenja odluka o postupanju na krajiškome području, a i sam je autor kao razloge za neuspjeh na habsburškome području istaknuo indiferentan odnos vojnih i kameralnih vlasti na kršćanskim područjima prema uniji koje je nisu odobravale jer su trebale vojnike kojima su dodjeljivane različite povlastice. No, istaknuo je i da je svaki pokušaj unije na osmanskome području - koji bi uključivao Pećku patrijaršiju s njezinim razvijenim institucijama i jasno oblikovanom religijskom, političkom i kulturnom misijom - otkrivao potpuni nedostatak osjećaja za realno stanje jer su takvi pokušaji uključivali samo izolirane pokušaje vladika i kaluđera koji su bili marginalni i u geografskom i organizacijskom smislu, i kojima je nedostajala bilo kakva jača crkvena ili svjetovna podrška. ${ }^{38}$

Završavajući ovaj tekst moramo napomenuti da su uz istraživanje crkvene unije i vjerske politike Habsburgovaca u Krajini u literaturi prisutne različite procjene o brojnosti krajišnika. Z. Kudelić je napomenuo da arhivsko gradivo posvećeno uniji navodi samo približne brojeve, koji se kreću od dvadeset do šezdeset tisuća Vlaha, a

38 Antal Molnár, Confessionalization on the Frontier. The Balkan Catholics between Roman Reform and Ottoman Reality (Roma: Viella, 2019), 163-167. 
jedna vatikanska isprava pisana na talijanskome jeziku iz vremena biskupa Benedikta Vinkovića spominje 100.000 katolika i 74000 Vlaha šizmatika, dok je zagrebački biskup Petar Petretić 1663. godine napomenuo da katolici u Krajini dvostruko ili trostruko premašuju Vlahe. K. Zach navela je da su pravoslavni kršćani sa Balkana ("Vlasi i Srbi”) u 17. stoljeću činili većinu stanovništva Hrvatsko-slavonske vojne krajine, ali nije detaljnije obrazložila na temelju kojih je podataka došla do toga zaključka. ${ }^{39}$ Prve preciznije podatke za Varaždinski generalat (Slavonsku krajinu) iznio je H. Petrić, prema čijim su istraživanjima pravoslavni Vlasi početkom 17. stoljeća činili nešto manje od polovice ukupnoga stanovništva Varaždinskoga generalata, a krajem toga stoljeća katolici i Vlasi činili su približno polovicu stanovništva. Petrićevi podaci vrlo su dragocjeni za poznavanje demografske povijesti toga dijela Vojne krajine jer pokazuju koliko su dosadašnji podaci bili nepouzdani i koliko je potrebno ovakvim istraživanjem obuhvatiti i ostale dijelove Krajine. ${ }^{40}$

\section{Zaključak}

Povijest grkokatoličke/unijatske Marčanske (Svidničke ili Platejske) biskupije i crkvene unije u Hrvatskoj tema je kojom su se u historiografiji u posljednja dva desetljeća bavili domaći i inozemni znanstvenici koji su istraživali povijest Vojne krajine, povijest Katoličke crkve ili su o ovoj temi govorili u sintezama povijesti Hrvatske. $\mathrm{Na}$ autore iz krugova Katoličke crkve znatno su utjecale teze J. Šimraka o uspjehu unije na početku 17. stoljeća kao posljedici širega unijatskoga pokreta i njezinome trajanju sve do dolaska pećkoga patrijarha Arsenija III. Crnojevića u Monarhiju te o odgovornosti Bečkog dvora i nekih zagrebačkih biskupa za njezin neuspjeh. S druge strane inozemni povjesničari prihvaćali su zaključke o habsburškoj vjerskoj politici iz austrijske historiografije druge polovice 19. stoljeća i ponavljali stereotipe i netočne podatke, na primjer tezu o isusovcima kao glavnim čimbenicima u širenju unije i stalnome katoličkom pritisku na pravoslavne krajišnike, koji da su provodili krajiški zapovjednici. Samo rijetki povjesničari upozorili su na njezinu neodrživost i istaknuli

39 Kudelić, Marčanska biskupija, 133-143, 166; Jačov, Spisi Kongregacije za propagandu vere, 364; HRNAZ-Epistolae epricoporum zagrabiensium, sv 1, dok. 99: “..quia tunc etiam Catholici qui actualiter cum Valachis premebantur, et injuribantur, cum ipsis Valachis unum sentiebant, Valachos alioquin in duplo, vel etiam triplo numero superantes...”; Krista Zach, “Konfessionelle Raumkonfigurationen in südostlichen Europa. Historiographischen Anmerkungen zur Frühneuzeit”, u: Kirchen als Integrationsfaktor für die Migranten im Südosten der Habsburgermonarchie im 18. Jahrhundert, ur. Rainer Bendel, Norbert Spannenberger (Berlin; Münster: Lit Verlag, 2010), 281.

40 Tijekom 18. stoljeća došlo je do pada broja pravoslavnoga stanovništva na $29 \%$ dok je udio katoličkoga stanovništva porastao na $71 \%$, a sredinom 19. stoljeću udio pravoslavnoga stanovništva pao je na $24 \%$. Petrić je procijenio da je u Varaždinskome generalatu živjelo početkom 17. stoljeća oko 15590 stanovnika, a krajem oko 50810 stanovnika, dok je u Križevačkoj županiji krajem 16. stoljeća bilo oko 12350, a krajem stoljeća 17. stoljeća 33580 stanovnika. Stanovništvo cijelog područja Križevačke županije i Varaždinskoga generalata prema njegovim istraživanjima poraslo je s 27940 na 84400 stanovnika do kraja tog stoljeća. Opširnije: Hrvoje Petrić, "Pokušaj rekonstrukcije ukupnog broja stanovnika Varaždinskog generalata i Križevačke županije od kraja 16. do početka 18. stoljeća”, Podravina 10 (2011), br. 16: 45-57; Petrić, Pogranična društva i okoliš, 337-339. 
da je krajiško područje za pravoslavne kršćane iz Osmanskoga Carstva - koje neki autori poistovjećuju sa Srbima, dok drugi spominju Vlahe - bilo poželjno područje za naseljavanje s obzirom na habsburšku religijsku politiku, a zbivanja tijekom 18 . stoljeća većina autora opisivala je vrlo šturo, oslanjajući se zbog nedostatka relevantnih radova na nepouzdanu stariju krajišku historiografiju. U domaćoj historiografiji primjetni su pomaci u istraživanju ove teme jer su pojedini autori kritički analizirali historiografiju i naglasili njezine manjkavosti, a povijest unije i Marčanske biskupije promatrali su u širemu kontekstu povijesti Vojne krajine i habsburške crkvene i religijske politike na jugoistoku Europe. Njihova istraživanja ispravila su pojedine netočne podatke o marčanskim biskupima i prikazala habsburšku vjersku politike kompleksnijom nego što je to činila prijašnja historiografija, a otvorena su i nova istraživačka pitanja, na primjer prevjeravanja u Krajini i katolička obnova na krajiškome području, kojima tek treba posvetiti detaljniju znanstvenu analizu. Međutim, uočljivo je da među autorima postoje bitne razlike u ocjeni početaka, motiva i dosega unije te različito razumijevanje temeljnih pojmova o ovoj problematici, o čemu tek treba slijediti detaljnija rasprava. 


\section{Neobjavljeni izvori}

Hrvatska - Nadbiskupijski arhiv u Zagrebu, Zagreb - Ecclesiastica, svežanj 8.

Hrvatska - Nadbiskupijski arhiv u Zagrebu, Zagreb - Epistolae episcoporum zagrabiensium, svežanj 1 .

\section{Literatura}

Adamček, Josip. Bune i otpori: seljačke bune u Hrvatskoj u XVII stoljeću. Zagreb: Globus, 1986.

Anzulović, Branimir. Mit o nebeskoj Srbiji. Polazište osvajačkih ratova i zločina u 20. stoljeću. Zagreb: Večernji posebni proizvodi, 2011.

Barišić, Rudolf. "Rafael Levaković i crkvena unija”. U: Zbornik o Rafaelu Levakoviću. Zbornik radova sa znanstvenog skupa "Fra Rafael Levaković". Šibenik-Skradin-Visovac 14. - 16. svibnja 2009., uredio Pavao Knezović, 47-82. Zagreb: Hrvatski studiji Sveučilišta u Zagrebu, 2010.

Bohn, Thomas M. "Vampirismus in Österreich und Preussen. Von der Entdeckung einer Seuche zum Narrativ der Gegenkolonisation”. Jahrbücher für Geschichte Osteuropas 56 (2008), br. 2: 161-177.

Bracewell, Wendy. "The Historiography of the Triplex Confinium: Conflict and Community on a Triple Frontier, $16^{\text {th }}-18^{\text {th }}$ centuries". U: Frontiers and the Writing of History, 1500-1850, uredili Steven G. Ellis, Raingard Eßer, 211-227. Hannover: Wherhahn, 2006.

Burić, Josip. Biskupije Senjska i Modruška u XVIII. stoljeću. Gospić; Zagreb: Kršćanska sadašnjost, 2002.

Burkhardt, Johannes. Vollendung und Neuorientierung des frühmodernen Reiches 16481763. Stuttgart: Klett-Cotta, 2006.

Fine, John. When Ethnicity Did not Matter in the Balkans. A Study of Identity in Pre-Nationalist Croatia, Dalmatia, and Slavonia in the Medieval and Early-Modern Periods. Ann Arbor: University of Michigan Press, 2006.

Forgo, András. Kirchliche Einigungsversuche in Ungarn. Die Unionsverhandlungen Christophorus Rojas Y Spinolas in der zweiten Hälfte des 17. Jahrhunderts. Mainz: Verlag Phillip von Zabern, 2007.

Ovidiu, Ghitta. "The first Greek Catholic catechisms in Hungary and Transylvania". U: Confessional Identity in East-Central Europe, uredili Maria Craciun, Ovidiu Ghitta, Graeme Murdock, 153-166. Farnham: Ashgate, 2002.

Grbić, Manojlo. Karlovačko vladičanstvo: prilog k istoriji Srpske pravoslavne crkve, knjiga I. Karlovac: Štamparija Karla Hauptfelda, 1891.

Grujić, Radoslav. Kako se postupalo sa srpskim molbama na dvoru cesara Austrijskog poslednje godine života patrijarha Arsenija III. Crnojevića. Novi Sad: Matica srpska, 1906.

Grujić, Radoslav. Pakračka eparhija. Istorijsko-statistički pregled. Spomenica o srpskom pravoslavnom vladičanstvu pakračkom u slavu četrdesetogodišnjice episkopstva, šezde- 
setgodišnjice svešteničke službe i osamdesetpetogodišnjice života vladike Mirona. Pakrac: Sveštenstvo vladičanstva Pakračkog, 1930.

Grulich, Rudolf. "Kirchliche Relikte der Militärgrenze”. U: Die Österreichische Milizärgrenze. Geschichte und Auswirkungen, uredio Gerhard Ernst, 34-39. Regensburg: Verlag Lassleben, 1982.

Hammerl, Franjo. "Pavao Zorčić - unijatski vladika. Povodom tristote godišnjice sjedinjenja naše braće unijata sa Rimskom crkvom 1611-1911”. Vrhbosna 25 (1911), br. 5: 68-72; br. 6: 83-88; br. 7/8: 101-105; br. 9: 136-139; br. 10: 147-151; br.11: 164-167.

Havadi-Nagy Kinga Xénia. Die Slawonische und Banater Militärgrenze. Kriegserfahrungen und räumliche Mobilität. Cluj-Napoca: Academia Românâ Centrul de Studii Transilvane, 2010.

Holjevac, Željko; Moačanin, Nenad. Hrvatsko-slavonska Vojna krajina i Hrvati pod osmanskom vlašću. Zagreb: Leykam International, 2007.

Hoško, Franjo Emanuel; Kovačić, Slavko. “Crkva u vrijeme katoličke obnove: Marčanska unija i neki slični pokušaji”. U: Hrvatska i Europa. Kultura, znanost i umjetnost, sv. III: Barok i prosvjetiteljstvo (XVII-XVIII. stoljeće), uredio Ivan Golub, 165-186. Zagreb: HAZU; Školska knjiga, 2003.

Ikić, Niko. "Der Begriff Union” im Entstehungsprozeß der unierten Diözese von Marča (Križevci,): eine ekklesiologisch-juridische Untersuchung auf Grund einer geschichtlichen Darlegung. St. Otilien: EOS-Verlag, 1989.

Ingrao, Charles W. The Habsburg Monarchy 1618-1815. Cambridge: Cambridge University Press, 1994.

Ivanišević, Goran. Marčanska unija 1611. Ljetopis i pojmovnik. Zagreb: vlastita naklada, 2012.

Ivanišević, Goran. Marčanska unija 1611. i Križevačka eparhija 1777. Ljetopis i pojmovnik. Zagreb: vlastita naklada, 2018.

Ivić, Aleksa. "Iz istorije crkve hrvatsko-slavonskih Srba tokom XVII. veka". Vjesnik Kraljevskog hrvatsko-slavonsko-dalmatinskog zemaljskog arkiva 18 (1916), br. 2: 1-82.

Ivić, Aleksa. "Iz istorije crkve hrvatsko-slavonskih Srba tokom XVII. veka". Vjesnik Kraljevskog hrvatsko-slavonsko-dalmatinskog zemaljskog arkiva 19 (1917), br. 2: 88-105.

Ivić, Aleksa. "Marčanska episkopija od Simeona Vretanje do Gavrila Predojevića (1609.1642.)”. Brastvo 17 (1923): 156-166.

Ivić, Aleksa. "Marčanska episkopija od Gavrila Predojevića do Gavrila Mijakića (16421660)”. Brastvo 18 (1924): 87-100.

Ivić, Aleksa. “Marčanska episkopija od 1662 do 1670”. Brastvo 19 (1925): 196-217.

Ivić, Aleksa. "Marčanska episkopija. Tragedija episkopa Mijakića i njegovih kaluđera”. Brastvo 20 (1926): 68-83.

Jačov, Marko. Spisi Kongregacije za propagandu vere u Rimu o Srbima 1622-1644 I. Srpska akademija nauka i umetnosti, Zbornik za istoriju, jezik i književnost srpskog naroda, II. odeljenje, knjiga 26. Beograd: SANU, 1986. 
Judah, Tim. The Serbs: History, Myth and the Destruction of Yugoslavia. New Haven; London: Yale University Press, 2000.

Kaser, Karl. Slobodan seljak i vojnik. Povojačenje agrarnog društva u Hrvatsko-slavonskoj Vojnoj krajini (1535.-1881.), sv. 2: Povojačeno društvo (1754-1881.). Zagreb: Naprijed, 1997.

Kašić, Dušan. Otpor Marčanskoj uniji. Lepavinsko-severinska eparhija. Beograd: Pravoslavlje, 1986.

Kašić, Dušan. Srpski manastiri u Hrvatskoj i Slavoniji. Beograd: Muzej Srpske pravoslavne crkve, 1996.

Kauzlarić, Nevenka. Tragom marčanske povijesti. Otok Ivanić: “Kloštar Ivanić”, 2010.

Klapka, Petr. Jean Louis Ratuit de Souches (1608-1681). De La Rochelle au service des Habsburgs. Contribution à l'étude des migrations nobiliaires francophones dans les pays de la Couronne de Bohême aux XVIIe-XVIIIe siècles. Paris: Honoré Champion, 2015.

Kolarić, Juraj. Ekumenska trilogija: istočni kršćani, pravoslavni, protestanti. Zagreb: Prometej, 2005.

Korade, Mijo. "Petar Domitrović 1611-1628”. U: Zagrebački biskupi i nadbiskupi, uredio Franko Mirošević, 297-305. Zagreb: Školska knjiga, 1995.

Korade, Mijo. “Benedikt Vinković 1637-1642”. U: Zagrebački biskupi i nadbiskupi, uredio Franko Mirošević, 321-322. Zagreb: Školska knjiga, 1995.

Korade, Mijo. “Petar Petretić 1647-1667”. U: Zagrebački biskupi i nadbiskupi, uredio Franko Mirošević, 337-339. Zagreb: Školska knjiga, 1995.

Kudelić, Zlatko. "Srpska pravoslavna crkva kao tema novijih istraživanja hrvatskih i inozemnih autora”. Časopis za suvremenu povijest 29 (1997), br. 1: 157-176.

Kudelić, Zlatko. "Srpska pravoslavna crkva u djelima hrvatskih i inozemnih autora između dva svjetska rata”. Časopis za suvremenu povijest 30 (1998), br. 3: 547-574.

Kudelić, Zlatko. "Rafael Levaković kao kandidat za biskupa grkokatoličke Marčanske biskupije". U: Hereditas rerum croaticarum ad honorem Mirko Valentić, uredili Alexander Buczynski, Milan Kruhek, Stjepan Matković, 113-124. Zagreb: Hrvatski institut za povijest, 2003.

Kudelić, Zlatko. "Prijedlog dvorskih savjetnika caru Leopoldu I. o smjenjivanju marčanskog biskupa Gabrijela Mijakića i sužavanju vlaških povlastica iz 1668. godine”. Croatica Christiana periodica 27 (2003), br. 51: 79-100.

Kudelić, Zlatko. "Povijest grkokatoličke Marčanske biskupije ('biskupije Vlaha') zagrebačkog biskupa Petra Petretića iz 1662. godine”. Povijesni prilozi 22 (2003), br. 25: 187-216.

Kudelić, Zlatko. “Izvješće zagrebačkog biskupa Petra Petretića o Svidničkoj (Marčanskoj) biskupiji caru Leopoldu I. iz 1667. godine”. Povijesni prilozi 23 (2004), br. 26: 69-97.

Kudelić, Zlatko. “Srpska pravoslavna crkva u Bosni i Hercegovini tijekom austrougarske vladavine u novijoj domaćoj i inozemnoj histriografiji”. Croatica Christiana periodica 32 (2008), br. 62: 29-62.

Kudelić, Zlatko. Marčanska biskupija. Habsburgovci, pravoslavlje i crkvena unija u Hrvatsko-slavonskoj vojnoj krajini 1611.-1755. Zagreb: Hrvatski institut za povijest, 2007. 
Kudelić, Zlatko. “Čaplovičeva povijest Marčanske biskupije”, Povijesni prilozi 29 (2010), br. 38: 135-182.

Kudelić, Zlatko. "Izvješće križevačkog pukovnika Johanna Josepha Herbersteina o Svidničkoj (Marčanskoj) biskupiji iz 1666. godine”. U: Ascendere historiam. Zbornik u čast Milana Kruheka, uredili Marija Karbić, Hrvoje Kekez, Ana Novak, Zorislav Horvat, 229247. Zagreb: Hrvatski institut za povijest, 2014.

Kudelić, Zlatko. "Konfesionalizacija i crkvena unija u Hrvatsko-Slavonskom Kraljevstvu na primjeru Vojne krajine”. U: Tridentska baština. Katolička obnova i konfesionalizacija u hrvatskim zemljama, uredile Zrinka Blažević, Lahorka Plejić Poje, 99-119. Zagreb: Matica hrvatska; Katolički bogoslovni fakultet u Zagrebu; Filozofski fakultet Družbe Isusove u Zagrebu.

Kurelac, Miroslav; Ladić, Zoran. "Pokret za odcjepljenje Hrvatskog Kraljevstva od Habsburške Monarhije”. U: Povijest Hrvata. Druga knjiga. Od kraja 15. stoljeća do kraja Prvog svjetskog rata, uredili Mirko Valentić, Lovorka Čoralić. Zagreb: Školska knjiga, 2005.

Louthan, Howard. "Multiconfesionalism in Central Europe". U: Thomas Max Safely, A Companion to Multiconfesionalism in the Early Modern World, ur. Thomas Max Safely, 369-392. Leiden; Boston: Brill, 2011.

Lukinović, Andrija. Zagreb-stoljetna biskupija. Zagreb: Glas koncila, 1995.

Macha, Josef. S. J. Ecclesiastical Unification. A Theoretical Framework Togerher With Case Studies From the History of Latin-Byzantine Relations. Roma: Pontificum Institutum Orientalium Studiorum, 1974.

Malcolm, Noel. Kosovo. A Short History. New York: NYU Press, 1998.

Matijević, Zlatko. Slom politike katoličkog jugoslavenstva: Hrvatska pučka stranka u političkom životu Kraljevine SHS (1919. - 1929.). Zagreb: Hrvatski institut za povijest, 1998.

Mirdita, Zef. Vlasi u historiografiji. Zagreb: Hrvatski institut za povijest, 2004.

Molnár, Antal. Confessionalization on the Frontier. The Balkan Catholics between Roman Reform and Ottoman Reality. Roma: Viella, 2019.

Nilles, Nicolaus. Symbolae ad illustrandam historiam Ecclesiae orientalis in terris coronae Sancti Stephani, I. Oeniponte: Typis et sumptibus Feliciani Rauch, 1885.

Ó hAnnracháin, Tadhg. Catholic Europe, 1592-1648. Centre and Peripheries. Oxford: Oxford University Press, 2015.

O'Reilly, William. "Border, Buffer and Bulwark. The Historiography of Military Frontier, 1521-1881". U: Frontiers and Writing of History, 1500-1850, uredili Steven G. Ellis, Raingard Eßer, 229-244. Hanover: Wehrhahn, 2006.

Orešković, Luc. "La notion de conversion aux frontières de l' Europe: un aspect du catholicisme dans le dioecèse de Senj-Modruš aux XVIIe et XVIIIe siècles". Croatica Christiana periodica 28 (2004), br. 53: 89-116.

Peklić, Ivan. "Prilozi za biografiju dr. Janka Šimraka”. Marulić 29 (1996), br. 2: 335-346; br. 6: 1155-1163; 30 (1997), br. 2: 365-373. 
Petrić, Hrvoje. "Katolička obnova i konfesionalne tolerancije / netolerancje na širem prostoru Triplexa Confiniuma do oko 1630. godine: primjer grada Koprivnice”. Croatica Christiana periodica 30 (2006), br. 57: 55-63.

Petrić, Hrvoje. "Roman Catholic Church and Confesional Revival. (In)tolerance in a Complex Borderland up to 1630s. Case study of the Town of Koprivnica". U: Tolerance and Intolerance on the Triplex Confinium. Approching the "Other" on the Borderlands: Esatern Adriatic and beyond 1500-1800, uredili Egidio Ivetić, Drago Roksandić, 253-251. Padova: Cleup, 2007.

Petrić, Hrvoje. "Pokušaj rekonstrukcije ukupnog broja stanovnika Varaždinskog generalata i Križevačke županije od kraja 16. do početka 18. stoljeća”, Podravina 10 ( 2011), br. 16: 45-57.

Petrić, Hrvoje. Pogranična društva i okoliš: Varaždinski generalat $i$ Križevačka županija u 17. stoljeću. Samobor; Zagreb: Meridijani; Društvo za hrvatsku ekonomsku povijest i ekohistoriju, 2012.

Pompiliu, Teodor. "The confessional identity of the Transylvanian Greek Catholic Church”. U: Confessional Identity in East-Central Europe, uredili Maria Craciun, Ovidiu Ghitta, Graeme Murdock, 167-180. Farnham: Ashgate, 2002.

Popović, Dušan. Velika seoba Srba 1690: Srbi seljaci i plemići. Beograd: Srpska književna zadruga, 1954.

Radonić, Jovan. Rimska kurija i južnoslavenske zemlje od XVI. do kraja XIX. veka. Posebna izdanja (Srpska akademija nauka i umetnosti), knjiga 155. Beograd: Naučna knjižara, 1950.

Roksandić, Drago. Etnos, konfesija, tolerancija. Zagreb: SKD Prosvjeta, 2004.

Rothenberg, Gunther Erich. The Austrian Military Border in Croatia, 1522-1747. Urbana: University of Illinois Press, 1960.

Ruvarac, Dimitrije. “Gavrilo Mijakić i Pavle Zorčić - marčanske vladike”. Srpski Sion 14 (1904), br. 11: 309-314.

Sekulić, Ante. “Tragovi Arsenija III. Crnojevića u Nadbiskupijskom arhivu u Zagrebu”. Tkalčić (1998), br. 2: 105-127.

Seewann, Gerhard. "Migrationen in Südosteuropa als Voraussetzung für die neuzeitliche West-Ostwanderung”. U: Migration nach Ost-und Südosteuropa vom 18. bis zum Beginn des 19. Jahrhunderts. Ursachen, Formen, Verlauf, Ergebnis (Schriftenreihe des Instituts für donauschwäbische Geschichte und Landeskunde, Band 4), uredili Matthias Beer, Dittmar Dahlmann, 95-100. Stuttgart: Franz Steiner Verlag, 1999.

Sladović, Manojlo. Poviesti biskupiah senjske i modruške ili krbavske. Trst: Austrianski Lloyd, 1856.

Smiljanić, Irena. "Zlatko Kudelić, Marčanska biskupija. Habsburgovci, pravoslavlje i crkvena unija u Hrvatsko-slavonskoj vojnoj krajini (1611.-1755.). Zagreb: Hrvatski institut za povijest, 2007., 585 str.". Ljetopis Srpskog kulturnog društva "Prosvjeta" 13 (2008): 462476. 
Spannenberger, Norbert. "Immigrationspolitik und interkonfessionelle Zusammenleben im 18. Jahrhundert in Süd-Transdanubien”. U: Kirchen als integrationsfaktor für die Migranten im Südosten der Habsburger Monarchie im 18. Jahrhundert, uredili Reiner Bendel, Norbert Spannenberger, 29-42. Berlin: LIT Verlag, 2010.

Steindorff, Ludwig. Povijest Hrvatske: od srednjeg vijeka do danas. Zagreb: Naklada Jesenski i Turk; Institut društvenih znanosti Ivo Pilar, 2006.

Suttner, Ernst Christoph. Staaten und Kirchen in der Völkerwelt des östlichen Europa. Entwicklungen der Neuziet. Fribourg: Academic Press, 2007.

Šanjek, Franjo. "Unijatska crkva i pravoslavlje u Hrvatskoj”. U: Povijest Hrvata. Druga knjiga: od kraja 15. st. do kraja prvog svjetskog rata, uredili Mirko Valentić, Lovorka Čoralić, 183-185. Zagreb: Školska knjiga, 2005.

Šimrak, Janko. "Povijest Marčansko-Svidničke eparhije i crkvene unije u Jugoslavenskim zemljama”. Bogoslovska smotra 12 (1924), br 1: 64-81; br. 2: 160-187; br. 3: 286-311; br. 4: 412-446.

Šimrak, Janko. "Marčansko-Svidnička eparhija za vrijeme vladika Gabre i Vasilija Predojevića i Save Stanislavića”. Bogoslovska smotra 13 (1925), br. 1: 33-35.

Šimrak, Janko. "Marčanska eparhija”. Bogoslovska smotra 18 (1930), br. 1: 31-73; 19 (1931), br. 1: 17-50; br. 2: 147-190.

Šimrak, Janko. De relationibus Slavorum Meridionalium cum Sancta Sede Apostolica saeculis XVII et XVIII. Zagreb: Hrvatska Bogoslovska Akademija, 1926.

Šimrak, Janko. Graeco-catholica Ecclesia in Jugoslavia. Dioecesis Crisiensis, olim Marčensis Historiae et hodiernus status. Zagreb: Narodna prosvjeta, 1931.

Šimrak, Janko. Borba za crkveno i vjersko jedinstvo (Apologija Pavla Zorčića). Zagreb: Tiskara Narodne prosvjete, 1932.

Šimrak, Janko. Arsenije III. Crnojević i unija. Zagreb: Tiskara Narodne prosvjete, 1935.

Šimrak, Janko. “Jedanaesti Marčanski Vladika Grgur Vučinić (1707-1709)”. U: Spomenica grkokatolika Križevačke biskupije za 1936. godinu, 97-111. Zagreb: Tiskara Narodne prosvjete, 1936.

Šimrak, Janko. "Dvanaesti marčanski vladika Rafael Marković”. U: Spomenica grkokatolika Križevačke biskupije za 1936. godinu, 112-166. Zagreb: Tiskara Narodne prosvjete, 1936.

Škiljan, Filip. "Vjerski prijelazi s pravoslavlja na rimokatoličku i grkokatoličku vjeroispovijest u Podravini između 1941. i 1945. godine”. Podravina 15 (2016), br. 29: 168-179.

Štefanec, Nataša. "Tolerance and Intolerance in the Croatian-Slavonian Kingdom at the Turn of the $17^{\text {th }}$ Century. Contest for Gomirje". U: Tolerance and Intolerance on the Triplex Confinium. Approching the "Other" on the Borderlands Esatern Adriatic and beyond 1500-1800, uredili Egidio Ivetić, Drago Roksandić, 125-151. Padova: Cleup, 2007.

Tanner, Marcus. Hrvatska-država stvorena u ratu. Zagreb: Barbat; Hrvatska sveučilišna naklada; Hrvatski institut za povijest, 1999.

Uhač, Josip. Marčanska biskupija (eparhija: neki povijesni-pravni pregledi). Zagreb: Glas Koncila, 1996. 
Velagić, Zoran. "The Croatian Author at the Frontier of Catholicism and Orthodoxy in Croaria”. U: Frontiers of Faith. Religious Exchange and the Constitution or Religious Identities 1400-1750, uredili Eszter Andor, István György Toth, 89-97. Budimpešta: Central European University; European Science Foundation 200.

Vitković, Dimitrije. "Patrijarh Arsenije III. Crnojević u Pakracu”. U: Starine Jugoslavenske akademije znanosti i umjetnosti 36, ur. Ferdo Šišić, 163-208. Zagreb: JAZU, 1918.

Vukšić, Dragan. Žumberački uskoci. Unijaćenje i odnarođivanje. Srpsko narodno vijeće: Zagreb, 2015.

Wolf, Josef. Entwicklung der ethnische Struktur des Banats 1890-1992 (Atlas Ost-Südosteuropa. Aktuelle Karten zu Ökologie, Bevölkerung und Wirtschaft). Beč: Östereichische Ost und Südosteuropa-Institut, 2004.

Zach, Krista. "Konfessionelle Raumkonfigurationen in südostlichen Europa. Historiographischen Anmerkungen zur Frühneuzeit". U: Kirchen als Integrationsfaktor für die Migranten im Südosten der Habsburgermonarchie im 18. Jahrhundert, uredili Rainer Bendel, Norbert Spannenberger, 273-292. Berlin; Münster: Lit Verlag, 2010. 


\section{Zlatko Kudelić}

\section{Recent Historiography on the Greek Catholic Diocese of Marčanska (Svid- nička / Platejska) and the Church Union in Croatia}

\section{Summary}

The author analyses Croatian and international historiography on the Greek Catholic diocese of Marčanska (Svidnička or Platejska) since the early 1990s, emphasizing that the increased interest in this topic at that time was partly driven by the political changes in Croatia and its surroundings. The topic has been in the focus of interest of historians dealing with the Military Frontier (Krajina) and the Catholic Church as well as authors of the syntheses of the history of Croatia and the Serbian Orthodox Church in Croatia. A number of scholars in Croatia have accepted J. Šimrak's conclusions about the success of the union in the early 17 th century as a consequence of the wider Union movement and the responsibility of the Vienna court and some Zagreb bishops for its failure. On the other hand, foreign historians have accepted conclusions about the Habsburg religious policy from Austrian historiography written in the second half of the 19th and the early 20 th century, repeating stereotypes and inaccurate data that were not scientifically evaluated, such as the hypothesis about the Jesuits as the main factors in the expansion of the union and the constant Catholic pressure on the population of the Orthodox frontier region, allegedly carried out by the Krajina commanders. Only a few historians have indicated the unsustainability of these hypotheses and pointed out that the Frontier was a desirable settlement area for Orthodox Christians from the Ottoman Empire. There are noticeable differences among the scholars as to the interpretation of the beginnings, motives, and reach of the union, as well as different understandings of the basic concepts concerning this issue, and due to the lack of relevant studies and the use of unreliable older historiography, these 18th-century events have been described very scantily and inaccurately, especially the reign of Charles VI. Croatian historiography has made some progress in researching this topic and some scholars have critically assessed the said historiography, highlighting its shortcomings and observing the history of the union and the Diocese of Marčanska in the broader context of the history of the Military Frontier and the Habsburg religious policy in Southeastern Europe. Their research results have corrected some inaccurate data on the bishops of this diocese and presented Habsburg religious policy as more complex than the previous historiography did, opening new research topics such as the conversions and the Catholic renewal in Krajina, to which a more detailed scholarly analysis has yet to be done.

Keywords: historiography, Church union, Orthodox Church, Marčanska Diocese, Zagreb Diocese, Peć Patriarchy, Vienna court, Roman Curia, Croatian-Slavonian Military Frontier, Walachians

* Zlatko Kudelić, Croatian Institute of History, Opatička 10, 10000 Zagreb, Croatia, E-mail: zkudelic@isp.hr 